\title{
Mitochondria: a new therapeutic target in chronic kidney disease
}

\author{
Simona Granata ${ }^{\dagger}$, Alessandra Dalla Gassa ${ }^{\dagger}$, Paola Tomei, Antonio Lupo and Gianluigi Zaza
}

\begin{abstract}
Cellular metabolic changes during chronic kidney disease (CKD) may induce higher production of oxygen radicals that play a significant role in the progression of renal damage and in the onset of important comorbidities. This condition seems to be in part related to dysfunctional mitochondria that cause an increased electron "leakage" from the respiratory chain during oxidative phosphorylation with a consequent generation of reactive oxygen species (ROS).

ROS are highly active molecules that may oxidize proteins, lipids and nucleic acids with a consequent damage of cells and tissues.

To mitigate this mitochondria-related functional impairment, a variety of agents (including endogenous and food derived antioxidants, natural plants extracts, mitochondria-targeted molecules) combined with conventional therapies could be employed.

However, although the anti-oxidant properties of these substances are well known, their use in clinical practice has been only partially investigated. Additionally, for their correct utilization is extremely important to understand their effects, to identify the correct target of intervention and to minimize adverse effects.

Therefore, in this manuscript, we reviewed the characteristics of the available mitochondria-targeted anti-oxidant compounds that could be employed routinely in our nephrology, internal medicine and renal transplant centers. Nevertheless, large clinical trials are needed to provide more definitive information about their use and to assess their overall efficacy or toxicity.
\end{abstract}

Keywords: Mitochondria, Oxidative stress, Chronic kidney disease, Antioxidant drugs, Natural plants extracts, Drugs

\section{Background}

\section{Chronic Kidney Disese (Ckd)}

During CKD, the progressive deterioration of renal function [1] induces several biological and clinical dysfunctions including alteration in cellular energetic metabolism, change in nitrogen input/output, protein malnutrition, resistance to insulin and considerable enhancement of synthesis of inflammation/oxidative stress mediators [2-6].

Several authors have reported that in CKD, even in the early stage, there is an abundant production of reactive oxygen species (ROS) [7] mainly due to an hyperactivation of the nicotinamide adenine dinucleotide phosphate (NADPH) oxidase [8-10], elevated synthesis of oxidative stress markers [e.g., F2-isoprostanes, malondialdehyde

\footnotetext{
*Correspondence: gianluigi.zaza@univr.it

${ }^{\dagger}$ Equal contributors

Renal Unit, Department of Medicine, University-Hospital of Verona, Piazzale A.
} Stefani 1, 37126 Verona, VR, Italy
(MDA), advanced oxidation protein products (AOPP)] and release of uremic toxins. The level of all these factors is inversely correlated with the glomerular filtration rate (GFR) [5, 11-13].

The early stages of CKD require nutritional and pharmacological interventions to minimize uremic symptoms and maintain volume homeostasis (conservative therapy), while in the final stage of renal failure these alterations may induce the development of severe and life-threatening clinical complications and renal replacement therapies (RRT: hemodialysis and peritoneal dialysis) are necessary.

Although necessary to ensure patients' survival, hemodialysis (HD) and peritoneal dialysis (PD) exacerbate oxidative stress $[14,15]$ by exposing blood to the contact with low biocompatible dialytic devices or fluids. In HD, the contact of peripheral blood mononuclear cells (PBMCs) with plastificants and filters [16] and the microbial contamination together with the release of pyrogens 
in dialysate induce ROS synthesis as part of the immune response [17-22]. Moreover, similarly to CKD, HD patients show an increased free radical-catalyzed peroxidation of arachidonoyl lipids with elevated production of lipid peroxidation products [MDA, 4-hydroxynonenal (HNE) and F2-isoprostanes] [23, 24]. Other markers of oxidative stress shown to be elevated in HD include lipid hydroperoxides, oxidized-LDL and AOPP [11, 25-30].

At the same time, plasma levels of both nonenzymatic (e.g., vitamin C, vitamin E) [31] and enzymatic antioxidants [e.g., superoxide dismutase (SOD) and catalase, glutathione peroxidase (GPx) and paraoxonase (PON1)] are reduced in CKD and HD patients [32-35].

The above mentioned imbalance between oxidants and antioxidants in patients with advanced renal impairment can accelerate renal injury progression and may contribute to the high rate of clinical complications in both CKD patients in conservative and dialysis treatment. Major complications include cardiovascular disease, atherosclerosis, amyloidosis and DNADamage-Associated Malignancy [36].

Additionally, oxidative stress together with altered nutritional status, inflammation and cardiovascular disease may determine the onset and development of that condition known as "MIA syndrome" described by Stenvinkel et al. [37].

Similarly, during peritoneal dialysis (PD) treatment, "unphysiological" fluids characterized by high lactate and glucose concentration, high osmolality and glucose degradation products (GDPs) [38] could determine local and systemic oxidative stress. The latter may be aggravated by chronic inflammation, diabetes, advanced age, and loss of antioxidants such as vitamins $\mathrm{C}$ and $\mathrm{E}[39,40]$.

Finally, it is unquestionable that oxidative stress is an important cofactor contributing also to immune system deregulation [41].

\section{Mitochondria and Ckd}

Mitochondria participate in numerous cellular functions including ion homeostasis, heme and steroid synthesis, calcium signaling, apoptosis [42-45]. The prominent role of this organelle is to generate energy for cellular metabolism by the oxidative phosphorylation system (OXPHOS).

Electrons derived from cellular metabolism reach the mitochondria through two coenzymes, nicotinamide adenine dinucleotide (NADH)- and flavin adenine dinucleotide (FADH2). Then they undergo a passage throughout the electron transport chain that consists of five protein complexes located in the inner mitochondrial membrane.

Electrons pass through complexes I, III and IV thanks to a proton gradient generated by the transport of these particles to the outer side of the inner mitochondrial membrane. Complex $\mathrm{V}$ then translates energy derived from electron transport to ATP synthesis [46] (Fig. 1).

In this process, the electron leakage from the respiratory chain induces the conversion of oxygen (0.4-4 \%) in superoxide radicals [47]. As a consequence mitochondria are the primary source of ROS.

Recent findings emphasize the involvement of mitochondria in progression of chronic kidney damage [48, 49] (Fig. 2) particularly due to a reduction in mitochondrial DNA (mtDNA) copy number, loss of mitochondrial membrane potential $(\Delta \psi \mathrm{m})$, and drop of ATP production [50]. Mitochondria are also involved in apoptosis and epithelial to mesenchymal transition of renal tubular epithelial cells contributing to the fibrogenic process [51].

Our group has recently demonstrated that the activity of Complex IV (a key regulator of respiratory chain activity) is reduced in PBMC of CKD/HD patients [49]. This causes a drop in ATP production and exacerbates oxidative stress because these dysfunctional organelles release a great amount of ROS. Interestingly the mitochondrial ROS are able to activate NLRP3 inflammasome and thus contribute to CKD-related chronic microinflammation [52].

This mitochondria-induced NLRP3 inflammasome activation has been also reported by other groups in animal model of proteinuria-induced renal tubular injury [53].

We also showed [54] a deregulated mitochondrialrelated intracellular machinery in uremic patients treated with peritoneal dialysis (PD). A group of genes encoding for mitochondrial biogenesis (PGC-1 $\alpha$, NRF1 and TFAM) and functional proteins $(\mathrm{COX} 6 \mathrm{C}, \mathrm{COX} 7 \mathrm{C}, \mathrm{UQCRH}$ and $\mathrm{MCAD}$ ) were down-regulated in $\mathrm{PD}$ compared to healthy subjects.

At once, nuclear factor erythroid 2-related factor 2 (NRF-2) and one of its target gene superoxide dismutase 2 (SOD2) were up-regulated in peritoneal dialysistreated patients in the attempt to neutralize ROS over-production.

However, whether these mitochondrial abnormalities represent a causative factor or an outcome of cellular injury during this process remains to be investigated.

\section{Mitocondrial-induced oxidative stress: a New therapeutic target in Ckd}

Mitochondria could be in future a valuable pharmacological target for patients with renal impairment and a variety of agents, combined with conventional therapies and an appropriate life style, targeting mitochondriaderived oxidative stress, could prevent and slow-down the progression of CKD and minimize the development of severe systemic complications.

Nevertheless, although the anti-oxidant properties of most of these agents are well known, their use in clinical nephrology are only partially investigated. 


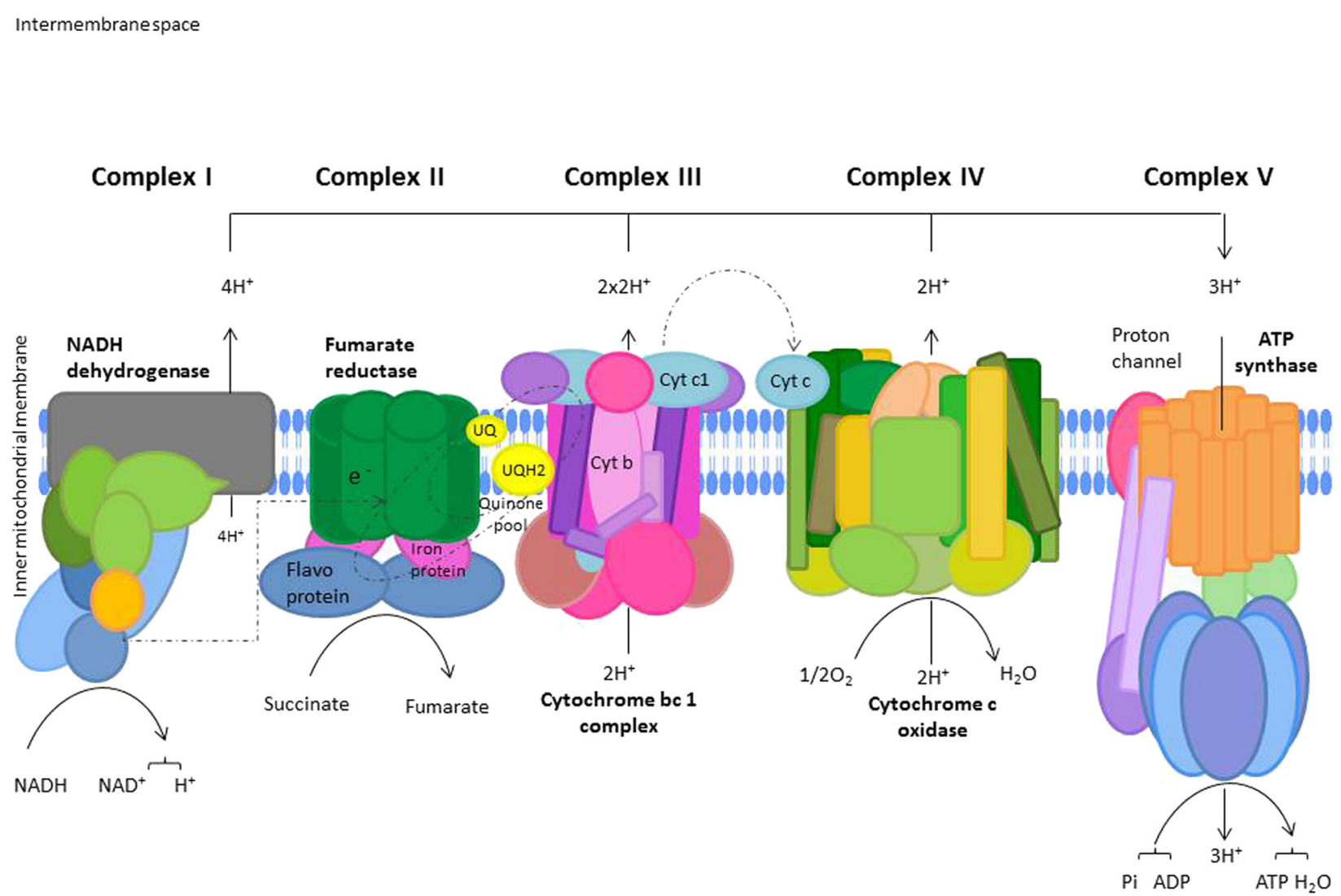

Mitochondrial matrix

Fig. 1 Oxidative Phosphorylation System (OXPHOS). Electrons derived from cellular metabolism reach complex I or complex II through NADH or $\mathrm{FADH}$ 2, respectively. These electrons are then transferred to coenzyme Q (ubiquinone), a carrier of electrons from complex I or II, to III. In the latter, particles are shifted form cytochrome b to cytochrome c with a consequent transfer to Complex IV (cytochrome oxidase) where they reduce O2. This electrons transport through mitochondrial complexes is coupled to shipment of protons in the intermembrane space. The electrochemical gradient generated is used by Complex $V$ for ATP synthesis. Adapted from the KEGG Oxidative phosphorylation pathway (Reference number: 00190, http://www.genome.jp/kegg-bin/show_pathway?map00190)

At the moment, the available mitochondria-targeted and anti-oxidant agents are (Fig. 3):

1. Endogenous and food derived antioxidants;

2. Natural plants extracts;

3. Conventional drugs with favorable antioxidant side effects;

4. Mitochondria-targeted molecules.

\section{Endogenous and food derived antioxidants L-Carnitine}

L-carnitine (4-N-trimethylammonium-3-hydroxybutyric acid) mainly derives from diet (75\%) with a bioavailability that ranges from 54-72 \% and it is synthesized endogenously (primarily in liver and kidney) from two essential amino acids: lysine and methionine [55].
It mediates the transport of fatty acids across the mitochondrial inner membrane from the cytosol to the mitochondrial matrix for their $\beta$-oxidation. This leads to acetyl coenzyme A production that, entering tricarboxylic acid cycle, improves mitochondrial respiratory chain activity and reduces ROS formation [56].

Additionally, L-carnitine is able to directly reduce free radical generation by scavenging ROS and chelating iron [57] and it may act as secondary antioxidant by increasing the production/activity of antioxidant enzymes and by inhibiting lipid peroxidation and xanthine oxidase activity $[58,59]$.

As demonstrated in animal model, L-carnitine reduces MDA content and restores glutathione (GSH) levels in aorta, heart and kidney tissues [60].

Patients with CKD in conservative therapy have higher plasma concentrations of L-carnitine than 


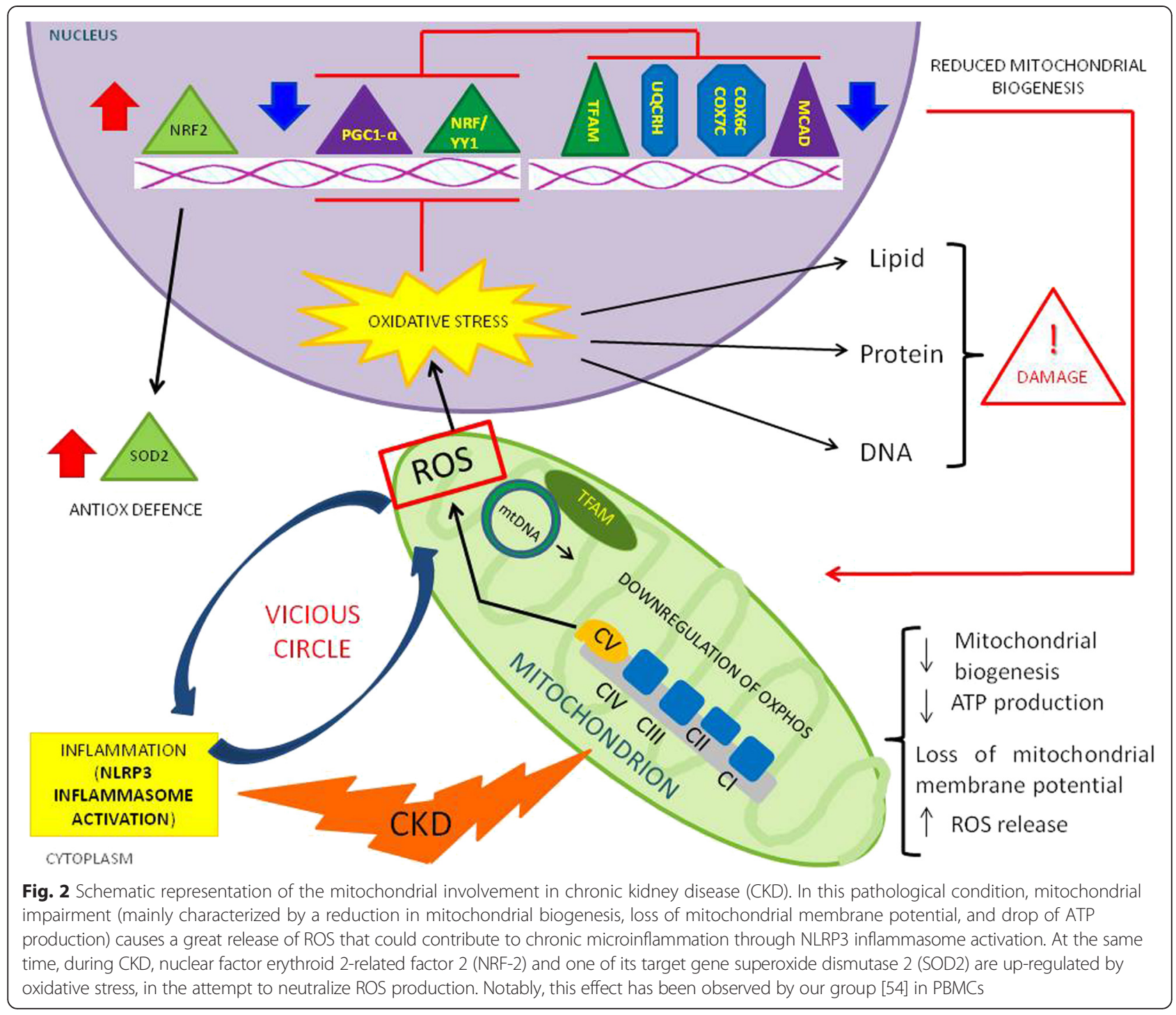

healthy individuals [61-64]. In contrast, a large number of studies have reported low plasma and muscle L-carnitine levels in CKD patients undergoing chronic hemodialysis [65-67] correlated with dialysis vintage $[61-64,68,69]$. This is mainly due to the efficient removal of the compound during the treatment together with a reduction in L-carnitine dietary intake and endogenous synthesis $[65,67,70]$.

The depletion in L-carnitine is associated with important clinical problems and symptoms, most notable of which are anemia hyporesponsive to erythropoietin therapy, intradialytic hypotension, cardiomyopathy and skeletal muscle dysfunction manifested as generalized fatigability [71].

Pertosa et al. [72], also, reported that 3 months supplementation of L-carnitine was also able to reduce intracellular levels of phosphorylated proteins and jun-N-terminal Kinase (JNK) activity in PBMC from HD patients treated with cellulosic membrane. This treatment caused a significant improvement of cellular defense against chronic inflammation and oxidative stress, most likely by modulating the specific signal transduction cascade activated by an overproduction of proinflammatory cytokines and oxidative stress.

Therefore, in the last years, the L-Carnitine supplementation in HD has been emphasized and several nephrology groups have started clinical research programs and trials. However, the results of most of these studies resulted unconvincing and conflicting. This could be due to the small population employed, the short duration of follow-up and the absence of a correct selection or adjustment for clinical manifestations [73-78].

Based on these clinical evidences, expert consensus groups and federal agencies have recommended LCarnitine not for routine use, but for dialysis patients with specific indications. In 1999, the FDA approved 


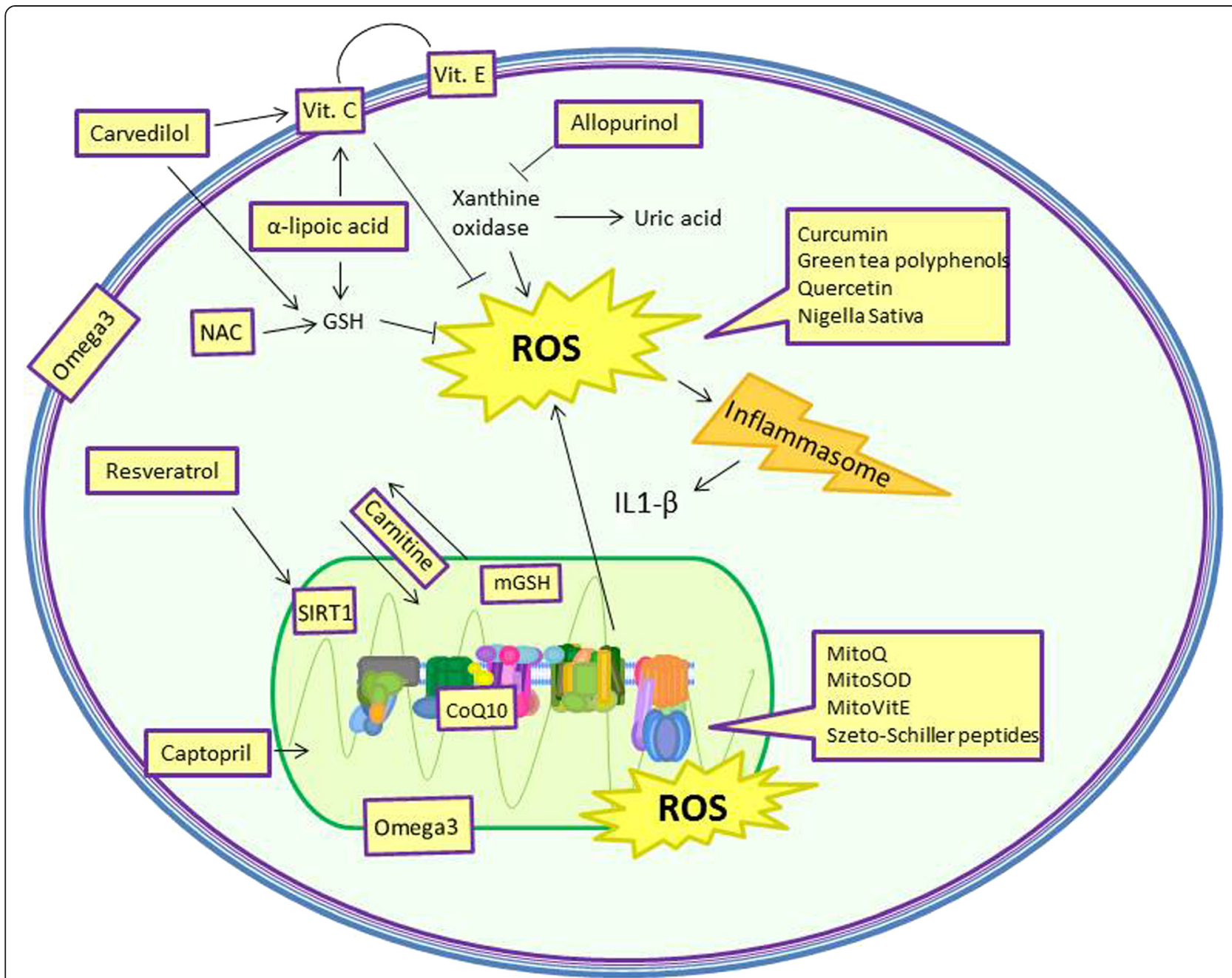

Fig. 3 Target sites of major anti-oxidants agents

intravenous L-Carnitine for use in dialysis-related carnitine deficiency, as defined by low L-Carnitine levels [79].

Subsequently, expert consensus panels of the American Association of Kidney Patients and of the National Kidney Foundation have recommended intravenous LCarnitine for treatment of erythropoietin-resistant anemia, dialysis hypotension, cardiomiophaty and muscle weakness [80]. Use of oral L-Carnitine was discouraged because of limited bioavailability, scarcity of supportive studies, and formation of toxic metabolities via intestinal metabolism.

\section{Coenzyme Q10 (CoQ10)}

CoQ10 is a biological element belonging to the mitochondrial electron transport chain that moves electrons from complex I/II to complex III [81] endogenously synthesized from tyrosine in several human tissues or introduced with diet (meat, fish, nuts, and some oils) [82].
Because its chemical characteristics (high molecular weight, strong lipophily, and weak solubility in water solution) CoQ10 has poor bioavailability in humans [83] .

It prevents membrane lipid peroxidation, apoptosis by inhibiting permeability transition pore (PTP) opening and mitochondrial membrane potential depolarization, and it is required for the uncoupling proteins function [84-86]. CoQ10 improves the oxygen consuming, ATP production and mitochondrial protein synthesis [87].

Moreover, CoQ10 is capable of recycling and regenerating other antioxidants such as tocopherol and ascorbate $[88,89]$. All these characteristics determine its clinical effects. In particular, CoQ10 may exerts important cardiovascular protective properties in patients affected by renal failure.

Atherosclerotic cardiovascular disease (CVD) is the main cause of high mortality rates among patients with advanced CKD [90]. This high incidence of cardiovascular (CV) death rate is 5-20 times higher in these 
patients population compared with those with normal renal function age and sex-matched and seems to be primarily associated with non-traditional risk factors as oxidative stress [91, 92].

Additionally, epicardial fat tissue (EFT), the visceral adipose tissue surrounding the subepicardial coronary vessels has recently been recognized as a new risk factor for atherosclerotic heart disease in PD and HD patients $[93,94]$. EFT is a lipid-storing depot $[95,96]$ and secretes proatherosclerotic and proinflammatory cytokines [97-99].

Macunluoglu et al., in accordance with previous studies [91, 100] demonstrated that Co-Q10 levels were significantly decreased in HD patients compared to healthy controls and inversely correlated with EFT thickness [101].

Authors hypothesized that increased EFT in HD patients can be another source of pro-inflammatory cytokines and pro-oxidant molecules which cause the consumption of Co-Q10 as antioxidant molecule. At the same time, the increased oxidative stress due to dialysis membranes, dialysate water and extracorporeal blood circulation could cause EFT overproduction as a part of the atherosclerotic process.

In another study it has been reported that Co-Q10 supplementation for 6 months reduces oxidative stress in HD patients but it was unclear whether this benefit would be translated into good clinical outcomes [100].

In an animal model Ishikawa et al. demonstrated that heminephrectomized rats fed with a CoQ10-supplemented diet showed lower levels of ROS and better renal function [102]. However, no clinical data strongly support this finding.

Moreover in mouse models of type 2 diabetes, CoQ10 introduction reduced oxygen consumption, mitochondrial fragmentation glomerular hyperfiltration and proteinuria [103, 104].

However, although these encouraging results, CoQ10 effects on CKD remain to be determined by additional in vivo studies and clinical trials.

\section{Alpha-lipoic acid (ALA)}

ALA is commonly found in vegetables (e.g., spinach, broccoli, tomato) and meat, but it can be also enzymatically synthesized by octanoic acid and cysteine in human mitochondria.

Because of its amphipathic structure is ubiquitously distributed in several cellular structures and in mitochondria where it acts as a cofactor for pyruvate dehydrogenase and $\alpha$-keto-glutarate dehydrogenase complexes.

Its neutralizes several free radicals [105], reduces the oxidized form of vitamin C and GSH, prevents the synthesis of free radicals by forming stable complex with the catalyzers $\mathrm{Mn}^{2+}, \mathrm{Cu}^{2+}$, and $\mathrm{Zn}^{2+}$ and chelating $\mathrm{Fe}^{2+}$ [106] and limits the inflammation through the inhibition of NFkB [107]. It is an inducer of NRF2-mediated antioxidant gene expression and activates PPAR- $\alpha$ and $-\gamma$ regulating the expression of several enzymes regulators of glucose and lipid metabolism [108].

Kim et al. reported, also, that ALA decreases vascular calcification by reducing vascular smooth muscle cells (VSMC) apoptosis by preserving anti-oxidant mitochondrial functions and activating Akt [109].

All these biochemical effects confer to this cofactor important antioxidant properties [110] that can be exploited in CKD patients to slow down the progression of renal damage and to control the onset of severe cardiovascular complications.

However, only few papers have described the clinical impact of ALA supplementation in CKD with contrasting results.

In a recent paper, HD patients receiving a daily dose of ALA (600 mg) for 8 weeks reported only a reduction in C-reactive protein (CRP) level, which is a risk factor for cardiovascular disease in this patients' population. It had no effects on MDA, total antioxidant status, total cholesterol, triglyceride, high-density lipoprotein cholesterol, and low-density lipoprotein cholesterol [111].

Contrarily, Chang and colleagues did not observe significant results in CRP levels by $600 \mathrm{mg}$ of ALA supplementation for 8 weeks in diabetic HD patients [112].

Similarly other two clinical trials, examining the anti-oxidant effects of ALA combined with mixed tocopherols in patients with CKD in both conservative and dialysis treatment, failed to give significant positive results $[113,114]$.

More recently, lipoic acid demonstrated positive effects in the treatment of diabetic nephropathy [115-118]. In particular, it was able to prevent renal insufficiency, glomerular mesangial matrix expansion, and glomerulosclerosis by restoring glutathione and reducing malondialdehyde levels [119].

We believe that such differences in outcomes might be primarily attributed to differences in genetic characteristics of patients and, in most studies, by limitations such as blind administration of study interventions, small sample size, and short period of follow-up. To avoid these strong biases, nephrological research community should undertake well organized multicenter international clinical trials.

\section{Omega 3 polyunsaturated fatty acids (Omega-3 PUFAs)}

Omega-3 are a family of polyunsaturated fatty acids (PUFAs) (including eicosapentanoic acid (EPA), docosapentaenoic acid (DPA) and docosahexanoic acid (DHA)) that play a major role in modulating the structure and function of cell and organelle membranes [120, 121]. A major source of these substances is the fish (mainly fish oil) [122]. 
They exert anti-inflammatory functions by reducing the expression/production of adhesion molecules, chemotactic factors, pro-inflammatory cytokines (TNF-a, IL-1b and IL-6) [123-125]. These effects are mainly due to the suppression of the $\mathrm{IkB}$ phosphorylation with a subsequent NFkB inactivation [126].

Moreover, being precursor of prostaglandins (I3 and E3), prostacyclins, thromboxanes A3 and leucotrienes B5, they have anti-thrombotic effects [127-129].

They also participate in membrane fluidity, ion channels transport (sodium, potassium and calcium) and mitochondrial biogenesis [130-132].

Additionally, they are also known to have antioxidant properties. They enhance endogenous antioxidant defense systems such as GSH through increased activity of $\gamma$-glutamyl-cysteinyl ligase, glutathione reductase and glutathione S-transferase [133]. DHA and EPA are incorporated into the phospholipid bilayer of cells where they displace arachidonic acid and reduce the ROS production by COX2 and xanthine oxidase pro-oxidant pathway [134].

From a clinical point of view, Omega-3 supplementation may have beneficial effects on lipid profile [135-137], blood pressure maintenance and redox status [138-141], together with important cardioprotective properties [142-144].

Additionally, some studies reported that fish oil therapy significantly reduced diastolic (7 to $15 \mathrm{mmHg}$ ) and/ or systolic blood pressure (16 to $30 \mathrm{mmHg}$ ) [145-147] in dialysis patients. However contrasting results have been published [148-150].

Several evidences suggest that thiobarbituric acid reactive substances (TBARS) level are reduced and SOD, glutathione peroxidase and catalase (CAT) activities increased after initiating treatment with Omega-3 [151]. Interestingly it has been demonstrated their ability to reduce 5- lipoxygenase activity, an enzyme responsible for apoptosis in PBMC of end stage renal disease patients [152, 153].

These findings were also confirmed in a study performed in a rat model of CKD supplemented with omega-3 for 12 weeks showed downregulation of prooxidant, proinflammatory and profibrotic pathways [154].

The long nephrology story of Omega-3 and these recently published studies in HD patients raised new hopes and, according to their authors, should promote randomized clinical trials with fish oil supplementation to improve cardiovascular outcomes in this setting.

However, as clearly suggested by Teta [155] the lessons learned from studies in non-dialysis settings, coupled with the consistent history of negative trials in the dialysis population, should invite caution. Further steps may be required before investment of resources in a randomized clinical trial with Omega-3 in this population.
Additional epidemiological evidence from larger samples of HD patients should be undertaken and interventional trials should be performed to define the best dose for each patient to reach sufficient blood levels of omega-3 fatty and to avoid complications (e.g., risk of bleeding especially in patients taking aspirin, clopidogrel, and anticoagulants, which are prevalent in CKD and cardiovascular disease population).

\section{Vitamin E}

Vitamin E indicates a group of 8 structurally related compounds (comprising $\alpha, \beta, \gamma, \delta$ tocopherol and the corresponding tocotrienols) [156]. However, $\alpha$-tocopherol having higher bioavailability in vivo, has been more extensively studied.

Vitamin E has been shown to regulate superoxide generation in human neutrophils and monocytes and mitochondrial ROS in skeletal muscle and liver [157-159]. This protective effect on oxidative stress attenuates the onset and development of several cardiovascular disease, aging and other chronic/degenerative diseases (including CKD).

Additionally, this vitamin has also been shown to mediate the activation and gene expression of protein kinase $C$ [160-162], transcription factor activator protein-1 [160, 163], transforming growth factor beta-1 [164], NFkB and related transcription factors [160, 165]. These factors are known to play important roles in mediating a number of pathophysiologic events including platelet adhesion and aggression and mural thrombus [166, 167], vascular smooth muscle cell proliferation [160, 168], apotosis [169] and glomerulosclerosis [170].

Therefore, dietary vitamin $\mathrm{E}$ intake by regulating the above mentioned biological/biochemical pathways and redox-sensitive biologic machineries could prevent or delay the progression of chronic systemic alterations (including chronic kidney damages) [159]. These protective effects have been also described in dialysis treated CKD patients [171, 172].

The SPACE study tested the cardiovascular preventive effects of vitamin E supplementation (administered at highdosage, $800 \mathrm{IU} /$ day) in HD patients with previous cardiovascular events. During the long follow-up (519 days) they found $40 \%$ reduction in both composite cardiovascularevents and myocardial infarction (70 \%) [173].

However, the beneficial effects of this agent in patients with renal damage is largely debated since a metaanalysis showed an increased mortality for all causes in patients affected by CKD treated with a daily dose > 400 IU [174].

Vitamin E seems also useful when bonded to dialysis membranes. In fact, in several studies oxidative stress and inflammatory markers were reduced together with an improvement in hemoglobin level and a reduction in Erythropoiesis-Stimulating Agents (ESA) requirement by 
long-term use of dialysis filters coated with vitamin $\mathrm{E}$ [175-179].

It is unquestionable that the results of the above mentioned studies suggest that vitamin E supplementation may be an effective accessory therapy to combat oxidative stress-lowering lipid peroxidation in CKD and HD patients. However, the correct clinical use of this vitamin in nephrology need to be better clarified.

\section{Vitamin C}

Vitamin C (ascorbic acid) is a water-soluble antioxidant found in some vegetables and fruits and distributed both in intra- and extracellular fluids. It scavenges ROS and reactive nitrogen species by forming semidehydroascorbic acid and may thereby prevent oxidative damage to important biological macromolecules [180].

It has been demonstrated that patients with CKD show a reduction in both the total Vitamin $C$ concentration and the active form (ascorbate) probably caused by a diminished intake of fruits and vegetables in order to avoid iperkaliemia and the loss during HD treatment [181-183]. Another possible explanation could be an impairment of enzymatic or non-enzymatic recycling of ascorbate from dehydroascorbate (the oxidized form of vitamin C), since the recycling is largely GSH dependent [184] and dialysis patients have a marked GSH deficiency [182].

To avoid this condition, currently, oral ascorbate/week $(1-1.5 \mathrm{~g})$, or parenteral ascorbate/dialysis session (300 mg), are recommended to compensate for subclinical deficiency, although evidence for such recommendations is scarce [183].

In a cross-over study, patients treated for three months with $200 \mathrm{mg} /$ day vitamin $\mathrm{C}$ showed decreased CRP level and augmented prealbumin concentration [185].

Additionally, 2 months treatment with intravenous vitamin $C$ in dialyzed patients using vitamin E-coated membranes significantly reduced oxidative stress, avoided the reduction of erythrocyte reductases activity and decreased the level of pro-inflammatory cytokines [179].

Ascorbic acid has also been used to improve response to ESA [186] through an increase in hemoglobin concentration and transferrin saturation. Use of ascorbic acid may enhance iron availability through 2 mechanisms: as a reducing agent that can mobilize iron from its storage sites and through its role of integration of iron into the heme moiety [187, 188].

Vitamin $\mathrm{C}$ has, also, anti-apoptotic effects by maintaining the mitochondrial membrane potential and protecting mtDNA from oxidant insults [189-192].

Although interesting, the use of this agent remains unusual in nephrology.

\section{Plant extracts with antioxidant properties Nigella sativa}

Nigella sativa (or black cumin) is a herbaceous plant growing particularly in Mediterrean area and in India [193] largely employed for culinary and medicinal purposes (treatment of pulmonary disorders, cardiovascular diseases, fever and influenza) [194]. Biological effects of Nigella sativa seeds seem to be related to their oil components.

Its seed oil contains an elevated quantity of polyphenols and tocopherols [195]. Thymoquinone (TQ) and its derivatives (dithymoquinone, thymohydroquinone, and thymol) [196] are the most abundant.

Their quinine structure confers to these molecules a significant antioxidant activity as scavenger of superoxide, hydroxyl radical and singlet molecular oxygen [197-199]. Additionally, TQ has anti-inflammatory property by inhibiting ecoisanoid, thromboxane B2 and leukotrienes B4 [200].

In medicine, TQ and its derivatives are tested as mitochondria-targeted antioxidants [201] and Nigella Sativa has been employed as preventive agent against doxorubicin (DOX), gentamicin, vancomycin and cisplatin nephro-toxicity $[202,203]$ by increasing glutathione peroxidase activity [204, 205] and against nephrotic syndrome-associated clinical complications [206].

As demonstrated by Badary et al. in a DOX-induced hyperlipidemic nephropathy rat model, treatment with TQ produced a significant reduction of nephritic syndromerelated clinical signs and complications (massive albuminuria, proteinuria, hyperlipidemia, hypoalbuminemia and hypoproteinemia). These signs resemble histologically and clinically focal and segmental glomerulosclerosis, one of the cause of CKD [206, 207]. The possible molecular mechanism for these positive effects could be a reduction of oxidative stress. In fact, although the exact molecular mechanism mediating the DOX-induced nephropathy remains unknown, it is believed that the toxicity may be mediated by ROS which cause glomerular injury and increased glomerular capillary permeability [208].

Cellular models have, also, clearly demonstrated that Nigella Sativa may have dose-related antiproliferative and cytotoxic effects [209-211].

According to these few published data, it is plausible that this agent may represent in future a new valid therapeutic tool in clinical nephrology, but at the moment, the absence of strong clinical evidences suggests a prudence in its employment in the treatment of patients with chronic renal disease.

\section{Curcumin}

Curcuma is a traditional Asian spice derived from the homonymous rhizome of the ginger family (Zingiberacee). 
It has been used in traditional Asian medicine (Ayurveda, Chinese, Arabian) for centuries. Recently a great number of studies have demonstrated that curcumin, the mean curcuminoid contained in Curcuma longa, exhibits high antiinflammatory and antibacterial properties [212-216].

Additionally, this agent can modulate several enzymes, cytokines, transcription factors, growth factors, receptors, micro RNA (miRNA) [217-219] that determine its dual antioxidant activity [220]. In detail, Curcumin is able to directly scavenge superoxide anion, hydroxyl radicals, $\mathrm{H}_{2} \mathrm{O}_{2}$, singlet oxygen, nitric oxide, peroxynitrite [221-225] and peroxyl radicals probably by means of phenolic groups in its molecular structure [222].

Curcumin has also indirect antioxidant ability mediated by the induction of the expression of cytoprotective proteins such as SOD, CAT [218], glutathione reductase (GR), glutathione peroxidase (GPx) [226], heme oxygenase 1 (HO-1) [227], glutathione-S-transferase (GST), NAD(P)H: quinone oxidoreductase 1 [228] and $\gamma$-glutamylcysteine ligase [229].

The potential therapeutic effects of Curcumin have been evaluated in several animal models of renal diseases [230-238] and clinical trials for cancer, Alzheimer's disease, ulcerative colitis, diabetes [217, 239].

Khajehdehi et al. have shown that, oral supplementation of turmeric/curcumin (one capsule with each meal containing $500 \mathrm{mg}$ turmeric, of which $22.1 \mathrm{mg}$ was the active ingredient curcumin-3 capsules daily for 2 months) has strong protective renal effects (reduction of proteinuria and inflammatory background) in patients with overt type-2 diabetic nephropathy together with a decrease in systolic blood pressure in patients suffering from relapsing or refractory lupus nephritis indicating a direct podocyte effect and making it a promising remedy for chronic glomerulonephritis and CKD [240, 241].

Finally, curcumin was able to induce a cardiovascular protection against CKD-associated cardiac remodeling, in part due to a preservation of the mitochondrial function [242].

However, at the moment, all these promising clinical evidences are not so sufficient to start a large utilization of this compound in our patients, but in future we believe that Curcumin could be employed in selected and well defined patients affected by glomerular pathologies and chronic renal impairment.

\section{Quercetin}

Quercetin (IUPAC nomenclature: 3, 3',4',5,7-pentahydroxyflavanone) is a flavonol presents in several aliments (e.g., onions, shallots, apples, berries, grapes, cappers, brassica vegetables, tea, red wine) [243] with strong antioxidant properties including scavenging of free radicals, inhibition of xanthine oxidase and decrement of lipid peroxidation [244-247]. Additionally, it has anti-inflammatory effects by suppressing the MAPK and NFkB signal transduction pathways [248], by modulating NOS and COX-2 synthesis and down-regulating CRP [249-251].

The renoprotective effect of this substance has been assessed in several models of toxic injury [252-254] and Shoskes et al. have shown that quercetin prevent renal injury in rodent models of ischemia/reperfusion and ureteral obstruction [255-257].

Interestingly the immune modulator effect of quercetin seems to be mediated also through two mechanisms: inhibition of the lymphocytes proliferation by arresting cell cycle in G1/S phase [258] and downregulation of IL-2 synthesis [259, 260]. These findings led to an open label phase I study in renal transplant recipients taking Oxy-Q which contains $400 \mathrm{mg}$ of curcumin and $100 \mathrm{mg}$ of quercetin [261]. In patients with poor renal function serum creatinine improved and in patients with delayed graft function, there was an enhancement in renal function.

Subsequently the same authors performed a randomized placebo controlled study with Oxy-Q started after renal transplantation and taken for 1 month. Patients were randomized into three groups: control (placebo), low dose (one capsule, one placebo) and high dose (two capsules). The high dose bioflavonoid group had the lowest serum creatinine values, the least neurotoxicity and an acute rejection rate at 6 months (including subclinical rejection) of $0 \%$ and the higher early graft function. Considering that urinary HO-1 was higher in bioflavonoid groups, authors suggested that these positive effects could be possible thanks to this enzyme induction [262]. HO-1 is a biological element able to reduce ischemia reperfusion damage and alloimmunity in renal transplant recipients [263]. However, authors conclude that these results were completely observational and the mechanism of the increased urinary HO-1 activity deserves further study [262].

Moreover, it has been suggested that Quercetin may also prevent tissue oxidative damages and attenuate renal damage in streptozotocin-induced diabetic rats [264-266].

As concern mitochondria Davis et al. reported that supplementation of quercetin for 7 days in mice induced PGC- $1 \alpha$ and Sirtuin 1 (SIRT1) mRNA up-regulation and enhanced mtDNA and cytochrome c concentration [267]. Quercetin inhibits complex I ability to generate $\mathrm{O}_{2}^{-}$[268].

It is also used as medication to treat cancer, cardiovascular diseases, systemic inflammation and gastrointestinal pathologies [269].

\section{Resveratrol}

Resveratrol (3,5,4'-trihydroxystilbene) is a natural phenol, contained in red wine and plants such as grapes, peanuts and berries [270]. It has antioxidant, anti- 
inflammatory, anti-mutagenic and anticancer properties [271-274].

This phytochemical exerts antioxidant effect by scavenging ROS directly and inducing the expression of several antioxidant enzymes such as SOD, CAT through NRF-2 [275].

Resveratrol activates the axis AMPK/SIRT-1/PGC- $1 \alpha$ [276], and attenuates aldosterone-induced mitochondrial dysfunction and podocyte injury [277].

Resveratrol inhibited both 5-lipooxygenase (LOX) and cyclooxygenase $(\mathrm{COX})$ activities resulting in a reduced accumulation of inflammatory mediators [278].

Thanks to its antioxidant mechanisms and influencing MAPK and TGF- $\beta 1 /$ Smad3 pathways, Resveratrol prevents epithelial to mesenchymal transition and renal fibrosis [279-284].

It has also been shown that this phenol may antagonize acute kidney injury due to cisplatin, ischemia-reperfusion and sepsis in animal models [285-287].

Unfortunately, resveratrol has poor bioavailability making difficult to translate the aforementioned in vitro findings into clinical trials [288]. At the moment several clinical trials on resveratrol are ongoing involving several metabolic and inflammatory systemic diseases.

\section{Green tea polyphenols}

The major polyphenols present in green tea are epigallocatechin 3-O-gallate, epicatechin 3-O-gallate, epigallocatechin and epicatechin. Beneficial actions of catechins are mostly due to the antioxidant properties, to the ability to chelate metal ions such as copper (II) and iron (III) and to form stable semiquinone free radicals [289-293]. The epigallocatechin-3-O-gallate (EGCG) is the most abundant and most active in green tea [294].

Several mechanisms have been linked to the antiinflammatory property of EGCG such as: a) Inhibition of NFkB [295] and b) activation of AMPK that inhibit the production of several proinflammatory mediators including TNF- $\alpha$, IL-1 $\beta$, IL-6, monocyte chemoattractant protein-1, inducible nitric oxide synthase (iNOS) and cyclooxygenase-2 with LPS stimulation [296-298]. More recently Qin et al. have also reported a direct interaction between EGCG and chemokines with a consequent limitation of their biological effects [299].

EGCG prevented the induction of vascular adhesion molecule- 1 by TNF $\alpha$ and IL-1, which subsequently reduced monocyte adhesion [300].

In rats subjected to unilateral ureteral obstruction, EGCG administration caused up-regulation and nuclear translocation of NRF2 with consequent enhancement of antioxidant enzymes such as glutathione peroxidase, glutathione S-transferase, $\gamma$-GCS and HO-1 [301].

At the same time EGCG alleviates glomerular and tubular injury and attenuates renal interstitial fibrosis through TGF- $\beta /$ Smad signaling pathway inhibition and NFkB upregulation [302, 303].

In Wistar rats subjected to ischemia-reperfusion renal damage together with LPS injection, the administration of EGCG reduces the activity of myeloperoxidase and protects kidney from peroxynitrite-induced damage [304].

Green tea polyphenols (daily dose, $400 \mathrm{mg}$ ) administered for 6 months to 50 patients on dialysis decreased the blood levels of methylguanidine [305] an uremic toxin that accumulates with the progression of renal failure. Furthermore, the same authors reported beneficial effects on renal function with green tea polyphenols administration to nephrectomized rats [306].

Also during diabetic nephropathy, EGCG leads to improvement of proteinuria, reduction of advanced glycosylation end products (AGE), hyperglycemia, lipid peroxidation thanks to its antioxidant activity and inhibition of NFkB [307].

Moreover, these substances may protect kidneys by several drugs such as ciclosporin, cisplatin, gentamicin through their anti-oxidative properties [308-310].

\section{Conventional drugs with antioxidant "side effects" \\ $\mathrm{N}$-acetyl cysteine (NAC)}

$\mathrm{N}$-acetylcysteine is a modified form of the amino acid cysteine, in which the nitrogen atom of the amino group is attached to an acetyl group. It has received attention because of its antioxidant capacity primarily due to its ability to drive the synthesis of the powerful antioxidant GSH [311]. Moreover NAC reacts fast and directly with radical $\mathrm{OH}$, radical $\mathrm{NO}^{2}, \mathrm{CO}^{--}$[312].

Upon deacetylation, NAC becomes L-cysteine, entering cells where it may serve as a precursor for GSH synthesis. In kidney subjected to ischemia/reperfusion injury GSH level is reduced and can be restored by NAC [313].

In cultured human proximal tubular epithelial cells, NAC reduced lipid peroxidation and maintained the mitochondrial membrane potential, thereby preventing apoptosis following $\mathrm{H} 2 \mathrm{O} 2$ administration [314].

NAC has an important vasodilatory effect maybe mediated by its ability to stabilize nitric oxide or by inhibiting angiotensin-converting enzyme [315, 316].

Since vasoconstriction is believed to be a pathogenic factor in contrast-induced nephropathy, vasodilatory effects may prove helpful and NAC has been the subject of numerous trials with mixed results [317-320]. The great difference in the clinical trials is the degree of risk of the patients involved. It seems to have positive effect on patients with renal dysfunction [321]. Another important point is the route of administration [322]. Given into account that NAC has an indirect effect, by acting on GSH metabolism, early dosing may be necessary [323]. Overall a positive effect of NAC on contrast- 
induced nephropathy is too far to come but since it is safe and well tolerated, intravenous NAC as a prophylactic agent for prevention of contrast-induced nephropathy is adequate [323].

Additionally, even if controversial, some studies showed beneficial effects of NAC supplementation in both PD and HD patients, such as increment in GFR, urine volume, reduction of IL-6 and MDA level and composite cardiovascular endpoints [324-328].

Interestingly, Tepel et al. conducted a prospective, randomized, placebo-controlled trial in $134 \mathrm{HD}$ patients randomly assigned either to receive acetylcysteine (600 mg BID) or placebo. The primary end point was a composite variable consisting of cardiac events including fatal and nonfatal myocardial infarction, cardiovascular disease death, need for coronary angioplasty or coronary bypass surgery, ischemic stroke, peripheral vascular disease with amputation, or need for angioplasty. Secondary end points included each of the component outcomes, total mortality, and cardiovascular mortality. In the acetylcysteine group $28 \%$ patients had a primary end point while $47 \%$ of the control group $(p=0.03)$. No significant differences in secondary end points or total mortality were detected [327].

Contrarily, several studies reported no effect of NAC supplementation neither on surrogate markers of cardiovascular injury nor on kidney function in patients with CKD [329-331].

The exact reasons for these negative results are not completely known, but they could be due to the relatively short treatment period and to a not standardized treatment dose. In fact, other authors reported that NAC has some value as an antioxidant, but only in certain conditions [332]. Moreover, at doses as low as 1200 mg daily, NAC may even exert pro-oxidative properties in people with normal intracellular GSH level [333]. However, these studies underline the necessity to undergo large multicenter trails to better define the therapeutic effect of NAC supplementation in CKD patients.

\section{Carvedilol and captopril}

Besides conventional use of carvedilol and captopril in the treatment of cardiovascular disease, these drugs explicate a potent antioxidant and anti-apoptotic activities.

Carvedilol is a nonselective beta-blocker, antagonizing $\beta-1$ and $\beta-2$ receptors with antioxidant properties attributed to the presence of a carbazole moiety in the molecule [334-336].

Several studies have reported protective effect of carvedilol against ischemia/reperfusion and drugs-induced nephrotoxicity [337-341].

Captopril is an angiotensin-converting enzyme (ACE) inhibitors with antioxidant properties due to a thiol group in its structure that has both the ability to scavenge free radical directly and to enhance antioxidant enzyme level [342, 343].

Experiments performed on a mouse model of acute kidney injury induced by ischemia/reperfusion demonstrated that captopril (an anti-hypertensive drug) determined important renal positive effects by inhibiting angiotensin-II activity and reducing parenchymal inflammation.

However, in the last phase of reperfusion, captopril was no longer effective [344].

\section{Allopurinol}

Allopurinol is a xanthine oxidase (XO) inhibitor used worldwide to treat hyperuricemia. $\mathrm{XO}$ is an enzyme that catalyzes the conversion of hypoxanthine to xanthine and finally to uric acid together with the production of ROS.

Uric acid is increased in CKD patients and is emerging as a potentially modifiable risk factor for CKD. The increment in uric acid results in oxidative stress and endothelial dysfunction with consequent development of systemic and glomerular hypertension in association with elevated renal vascular resistance and reduced renal blood flow [345-347]. Hyperuricemia was also able to induce an epithelial-to-mesenchymal transition, with direct effects on the tubular cell population [348].

There are several mechanisms mediating these effects: uric acid stimulates vascular smooth muscle cell proliferation with the activation of mitogen-activated protein kinases (MAPK) [349, 350], growth factors (PDGF), chemokines (monocyte chemoattractant protein1 [MCP-1]), and inflammatory enzymes (COX-2) [351]. On endothelial cells, uric acid activates the reninangiotensin system with augmented apoptosis and vascular dysfunction [352, 353].

Moreover long-term hyperuricemia induces hypertension, renal vasoconstriction, tubular damage, renal cortex oxidative stress, and mitochondrial impairment shown by oxidative phosphorylation uncoupling, reduced ATP renal content and lower mitochondrial DNA [354]. Treatment with allopurinol prevented these alterations [355].

In humans, several trials have reported beneficial effect of treatment with allopurinol on progression of kidney disease and cardiovascular events [356-361].

\section{Mitochondria-targeted molecules}

Although interesting, the conventional antioxidants are still far from a practical clinical employment. In fact, a great limitation of these antioxidants is their inability to reach in vivo an adequate mitochondrial concentration [362]. Therefore, in the last years, a great number of research strategies have been developed to minimize this condition.

Firstly, most of these molecules were synthesized by conjugating well known antioxidants with the lypophylic 
triphenylphosphonium (TPP) cation that enables such compounds to move rapidly through biological membranes and, because of its positive charge, to drive them inside mitochondria [363].

The first produced mitochondria-targeted antioxidant was MitoE, which comprises the $\alpha$-tocopherol moiety of vitamin $\mathrm{E}$ conjugated to TPP by a two carbon chain [364]. MitoE is taken up rapidly by mitochondria making this molecule more effective than the untargeted $\alpha$ tocopherol to prevent lipid peroxidation.

With the same research and technical approach it has been synthetized MitoQ, a quinone moiety linked to TPP by a 10-carbon alkyl chain [365-367]. MitoQ accumulation within mitochondria is driven by the membrane potential and it is absorbed to the matrix surface of the inner membrane where it exerts its protective effects against lipid peroxidation [366].

In animal models, MitoQ has been employed in several studies aimed to verify its protective effects against diseases involving mitochondrial oxidative damage (e.g., cardiac ischemia/reperfusion injury [368], endothelial damage induced by hypertension [369]).

MitoQ added to the cold storage fluid used to preserve the organ before kidney transplantation, prevented mitochondrial dysfunction, improved cell viability and renal morphology [370]. Likewise mitoQ intravenously administered to mice $15 \mathrm{~min}$ prior to occlude the renal vessels exerts protective effects on renal function and against oxidative damage [371, 372].

Also in a mouse model of diabetic nephropathy this compound demonstrated an important anti-fibrotic activity and a defensive effect against chronic glomerular damage [373].

From a clinical point of view, MitoQ (generally administered at oral dosing of $1 \mathrm{mg} / \mathrm{kg}$ ) has undergone phase I and II clinical trials [374, 375].

Another interesting mitochondria-targeted molecule is MitoSOD, designed by attaching TPP to the pyridine ring of M40403 (a non-peptidyl mimetic of MnSOD). This agent accumulates into mitochondria and it protects against oxidative damage induced by $\mathrm{O}_{2}{ }^{-}[376,377]$. At our knowledge, no clinical trials using this molecule are ongoing.

Mito-TEMPO, then, a nitroxide linked to TPP, with similar effects to MitoSOD, has positive effects in hypertension-related vascular injury by reducing the $\mathrm{O}_{2}^{-}$ and increasing the bioavailability of nitric oxide with subsequent endothelial-dependent relaxation [378].

In addition, MitoTempo $(10 \mathrm{mg} / \mathrm{kg})$ given at $6 \mathrm{~h}$ post cecal ligation and puncture (CLP) in a murine model of sepsis demonstrated reversed mitochondrial impairment together with an improvement in renal microcirculation and glomerular filtration rate [379].

In order to ameliorate the mitochondrial up-take of targeted molecules, in the last years, researchers are introducing new agents such as Szeto-Schiller (SS) peptides, promising molecules constituted by alternating aromatic residues and basic amino acids that have some features rendering them potent antioxidants: (1) they are taken up into cells in an energy-independent nonsaturable manner, (2) have a sequence motif that targets them to mitochondria, (3) are very potent in reducing intracellular ROS and preventing cell death at very low concentration [380-382] and (4) their uptake is not dependent on mitochondrial membrane potential. The antioxidant ability seems due to a tyrosine or 2,6-dimethyl-L-tyrosine (Dmt) residues and to their position in the sequence [381, 383].

These peptides have been tested in several animal models of oxidative damage such as myocardial infarction, ischemia reperfusion, amyotrophic lateral sclerosis, and pancreatic islet cell transplantation [384-388]. In a rat model of CKD performed by unilateral ureteral obstruction, SS-31 (1 or $3 \mathrm{mg} / \mathrm{kg}$ ) given 1 day before and throughout the 14 days of obstruction, significantly decreased tubular apoptosis, macrophage infiltration, fibrosis and it increased tubular proliferation [389].

In a rat model of ischemia/reperfusion SS-31 was administered subcutaneously $30 \mathrm{~min}$ before a 30 or $45 \mathrm{~min}$ long bilateral occlusion of renal blood flow, at the onset of reperfusion and $2 \mathrm{~h}$ later. It preserved renal tubular architecture, reduced apoptosis and maintained mitochondrial integrity and function with full recovery of ATP content after reperfusion. As a consequence, oxidative stress and inflammation were reduced and tubular cell regeneration was accelerated [390].

Interestingly, Liu et al. have demonstrated protective properties of SS-31 during ischemia/reperfusion also in capillary endothelial cells. As reported in tubular epithelial cells, SS-31 protects mitochondrial structure and prevents endothelial cell swelling, cell detachment and cell death [391]. The mechanism seems to be mediated by an interaction between SS-31 and cardiolipin, an anionic phospholipid expressed in the inner mitochondrial membrane. This interaction prevents cardiolipin peroxidation by inhibiting cytocrome c peroxidase activity [392].

SS-31 is now under evaluation in a multinational clinical trial for reperfusion injury in patients with acute coronary events (NCT01572909), and in a Phase 2 trial to assess the effectiveness on improving renal function after angioplasty for severe renal artery stenosis (NCT01755858).

Then, on the basis of SS-31, more recently Cerrato and coworkers have synthesized novel peptides called mitochondrial cell-penetrating peptides (mt-CPPs). CPP are short, nontoxic peptides with amphypathic and cationic properties able to cross the cellular membrane [393]. MtCCP-1 is not toxic even at high concentration, did not perturb $\Delta \psi \mathrm{m}$ and, interestingly, its amount into the cells is higher than SS-31 [393]. 
There are numerous CPPs available with different sequence and physicochemical properties that can be conjugated with different cargoes (small drugs, peptide or larger cargoes such as oligonucleotide, proteins and plasmids) very useful to deliver drugs into the target of interest [394].

\section{Conclusions}

Emerging evidences suggest that dysfunctional mitochondria have a primary role in the development of CKD as well as in comorbidities related to CKD and underline their role as new therapeutic targets.

A variety of agents (including endogenous and food derived antioxidants, natural plants extracts, mitochondriatargeted molecules) combined with conventional therapies and an appropriate life style could help clinicians to reach this objective. However, for a correct utilization of these agents is extremely important to understand their effects and to identify the correct target of interventions. In fact, although the beneficial effects of these compounds are well known, large clinical trials are needed to provide more definitive information on their efficacy in CKD.

Finally, future strategies (including pharmacogenomics [395]) should be undertaken to identify target patients potentially responsive to mitochondria-related anti-oxidant treatments.

\begin{abstract}
Abbreviations
CKD: Chronic kidney disease; HD: Hemodialysis; PD: Peritoneal dialysis; RRT: Renal replacement therapies; ROS: Reactive oxygen species; PBMC: Peripheral blood mononuclear cells; GDP: Glucose degradation products; OXPHOS: Oxidative phosphorylation system; NADH: Nicotinamide adenine dinucleotide; FADH2: Flavin adenine dinucleotide; PGC-1a: Peroxisome proliferator-activated receptor c coactivator 1; NRF1: Nuclear respiratory factor 1; TFAM: Mitochondrial transcription factor A; COX6C: Cytochrome c oxidase subunit VIc; COX7C: Cytochrome c oxidase subunit VIIc; UQCRH: Ubiquinolcytochrome $\mathrm{c}$ reductase hinge protein; MCAD: Medium-chain acyl-CoA dehydrogenase; SOD2: Superoxide dismutase 2; GSH: Glutathione; JNK: Jun-Nterminal Kinase; CoQ10: Coenzyme Q10; PTP: Permeability transition pore; NFkB: Nuclear factor kappa B; ALA: Alpha-lipoic acid; VSMC: Vascular smooth muscle cells; MDA: Malondialdehyde; PUFA: Polyunsaturated fatty acids; EPA: Eicosapentanoic acid; DPA: Docosapentaenoic acid; DHA: Docosahexanoic acid; TBARS: Thiobarbituric acid reactive substances; ESA: ErythropoiesisStimulating Agents; CRP: C-reactive protein; TQ: Thymoquinone; NRF2: Nuclear factor (erythroid-derived 2)-like 2; CAT: Catalase; NOS: Nitric oxide synthase; COX2: Cyclooxygenase-2; AMPK: 5' AMP-activated protein kinase; SIRT1: Sirtuin 1; LOX: 5-lipooxygenase; TGF- $\beta$ : Transforming growth factor beta; EMT: Epithelial to mesenchymal transition; LPS: Lipopolysaccharide; EGCG: Epigallocatechin-3gallate; MG: Methylguanidine; NAC: N-acetyl cysteine; ACE: Angiotensinconverting enzyme; a-SMA: Alpha smooth muscle actin; SS: Szeto-Schiller.
\end{abstract}

\section{Competing interests}

The authors declare that there is no conflict of interests regarding the publication of this article.

\section{Authors' contributions}

GZ, SG and AdG searched the literature and wrote the manuscript. PT contributed to the literature search literature analysis. AL revised the manuscript. All authors read and approved the final manuscript.

Received: 2 July 2015 Accepted: 18 November 2015

Published online: 25 November 2015

\section{References}

1. Kidney Disease. Improving Global Outcomes (KDIGO) CKD Work Group. KDIGO 2012 Clinical Practice Guideline for the Evaluation and Management of Chronic Kidney Disease. Kidney Int Suppl. 2013:3:1-150.

2. Slee AD. Exploring metabolic dysfunction in chronic kidney disease. Nutr Metab (Lond). 2012;9:36.

3. Siew ED, Ikizler TA. Insulin resistance and protein energy metabolism in patients with advanced chronic kidney disease. Semin Dial. 2010;23(4):378-82

4. Kobayashi S, Maesato K, Moriya H, Ohtake T, Ikeda T. Insulin resistance in patients with chronic kidney disease. Am J Kidney Dis. 2005;45(2):275-80.

5. Dounousi E, Papavasiliou E, Makedou A, loannou K, Katopodis KP, Tselepis A, et al. Oxidative stress is progressively enhanced with advancing stages of CKD. Am J Kidney Dis. 2006;48(5):752-60.

6. Cachofeiro V, Goicochea M, de Vinuesa SG, Oubiña P, Lahera V, Luño J. Oxidative stress and inflammation, a link between chronic kidney disease and cardiovascular disease. Kidney Int Suppl. 2008;111:S4-9.

7. Oberg BP, McMenamin E, Lucas FL, McMonagle E, Morrow J, Ikizler TA, et al. Increased prevalence of oxidant stress and inflammation in patients with moderate to severe chronic kidney disease. Kidney Int. 2004;65:1009-16.

8. Babior BM. NADPH oxidase: an update. Blood. 1999;93:1464-76.

9. Galli F, Varga Z, Balla J, Ferraro B, Canestrari F, Floridi A, et al. Vitamin E, lipid profile, and peroxidation in hemodialysis patients. Kidney Int. 2001;59 Suppl 78:S148-54.

10. Fortuño A, Beloqui O, San José G, Moreno MU, Zalba G, Díez J. Increased phagocytic nicotinamide adenine dinucleotide phosphate oxidasedependent superoxide production in patients with early chronic kidney disease. Kidney Int Suppl. 2005;99:S71-5.

11. Witko-Sarsat V, Friedlander M, Capeillère-Blandin C, Nguyen-Khoa T, Nguyen AT, Zingraff J, et al. Advanced oxidation protein products as a novel marker of oxidative stress in uremia. Kidney Int. 1996;49(5):1304-13.

12. De Vecchi AF, Bamonti F, Novembrino C, Ippolito S, Guerra L, Lonati S, et al. Free and total plasma malondialdehyde in chronic renal insufficiency and in dialysis patients. Nephrol Dial Transplant. 2009;24(8):2524-9.

13. Vanholder R, Argilés A, Baurmeister U, Brunet P, Clark W, Cohen G, et al. Uremic toxicity: present state of the art. Int J Artif Organs. 2001;24(10):695-725.

14. Amore A, Coppo R. Immunological basis of inflammation in dialysis. Nephrol Dial Transplant. 2002;17 Suppl 8:16-24.

15. Canaud B, Cristol J, Morena M, Leray-Moragues H, BosC J, Vaussenat F. Imbalance of oxidants and antioxidants in haemodialysis patients. Blood Purif. 1999;17(2-3):99-106.

16. Gesualdo L, Pertosa G, Grandaliano G, Schena FP. Cytokines and bioincompatibility. Nephrol Dial Transplant. 1998;13(7):1622-26.

17. Lazarus JM, Owen WF. Role of bioincompatibility in dialysis morbidity and mortality. Am J Kidney Dis. 1994;24(6):1019-32

18. Ritz E, Deppisch R, Stier E, Hänsch G. Atherogenesis and cardiac death: are they related to dialysis procedure and biocompatibility? Nephrol Dial Transplant. 1994;9 Suppl 2:165-72.

19. Kadkhodaee M, Hemmati M, Zahmatkesh M, Ghaznavi R, Mirershadi F, Mahdavi-Mazde $\mathrm{M}$, et al. Assessment of plasma antioxidant status in hemodialysis patients. Ther Apher Dial. 2008;12(2):147-51.

20. Cristol JP, Canaud B, Rabesandratana H, Gaillard I, Serre A, Mion C. Enhancement of reactive oxygen species production and cell surface markers expression during hemodialysis. Nephrol Dial Transplant. 1994;9:389-94.

21. Descamps-Latscha B, Goldfarb B, Nguyen AT, Landais P, London G, Haeffner-Cavaillon $\mathrm{N}$, et al. Establishing the relationship between complement activation and stimulation of phagocyte oxidative metabolism in hemodialyzed patients: a randomized prospective study. Nephron. 1991;59:279-85.

22. Chen MF, Chang CL, Liou SY. Increase in resting levels of superoxide anion in the whole blood of uremic patients on chronic hemodialysis. Blood Purif. 1998;16:290-300.

23. Sommerburg O, Grune T, Hampl H, Riedel E, van Kuijk FJ, Ehrich JH, et al Does long-term treatment of renal anaemia with recombinant erythropoietin influence oxidative stress in haemodialysed patients? Nephrol Dial Transplant. 1998;13:2583-7.

24. Handelman GJ, Walter MF, Adhikarla R, Gross J, Dallal GE, Levin NW, et al. Elevated plasma F2-isoprostanes in patients on long-term hemodialysis. Kidney Int. 2001;59:1960-6.

25. Kuchta A, Pacanis A, Kortas-Stempak B, Cwiklińska A, Ziętkiewicz M, Renke $\mathrm{M}$, et al. Estimation of oxidative stress markers in chronic kidney disease. Kidney Blood Press Res. 2011;34(1):12-9. 
26. Tbahriti HF, Kaddous A, Bouchenak M, Mekki K. Effect of different stages of chronic kidney disease and renal replacement therapies on oxidantantioxidant balance in uremic patients. Biochem Res Int. 2013;2013:358985.

27. Montazerifar F, Hashemi M, Karajibani M, Dikshit M. Hemodialysis alters lipid profiles, total antioxidant capacity, and vitamins $A, E$, and C concentrations in humans. J Med Food. 2010;13(6):1490-3.

28. Himmelfarb J, McMonagle E, McMenamin E. Plasma protein thiol oxidation and carbonyl formation in chronic renal failure. Kidney Int. 2000;58:2571-8.

29. Odetti P, Garibaldi S, Gurreri G, Aragno I, Dapino D, Pronzato MA. Protein oxidation in hemodialysis and kidney transplantation. Metabolism. 1996;45:1319-22.

30. Himmelfarb J, McMenamin ME, Loseto G, Heinecke JW. Myeloperoxidasecatalyzed 3-chlorotyrosine formation in dialysis patients. Free Radic Biol Med. 2001;31:1163-9.

31. Vaziri ND. Roles of oxidative stress and antioxidant therapy in chronic kidney disease and hypertension. Curr Opin Nephrol Hypertens. 2004;13:93-9.

32. Ceballos-Picot I, Witko-Sarsat V, Merad-Boudia M, Nguyen AT, Thévenin M, Jaudon MC, et al. Glutathione antioxidant system as a marker of oxidative stress in chronic renal failure. Free Radic Biol Med. 1996;21:845-53.

33. Chauhan DP, Gupta PH, Nampoothiri MR, Singhal PC, Chugh KS, Nair CR. Determination of erythrocyte superoxide dismutase, catalase, glucose-6phosphate dehydrogenase, reduced glutathione and malonyldialdehyde in uremia. Clin Chim Acta. 1982;123:153-9.

34. Roxborough HE, Mercer C, McMaster D, Maxwell AP, Young IS. Plasma glutathione peroxidase activity is reduced in haemodialysis patients. Nephron. 1999;81:278-81.

35. Dantoine TF, Debord J, Charmes JP, Merle L, Marquet P, Lachatre G, et al Decrease of serum paraoxonase activity in chronic renal failure. J Am Soc Nephrol. 1998;9:2082-8.

36. Becker BN, Himmelfarb J, Henrich WL, Hakim RM. Reassessing the cardiac risk profile in chronic hemodialysis patients: A hypothesis on the role of oxidant stress and other non-traditional cardiac risk factors. J Am Soc Nephrol. 1997:8:475-86.

37. Stenvinkel $P$, Heimbürger $O$, Lindholm B, Kaysen GA, Bergström J. Are there two types of malnutrition in chronic renal failure? Evidence for relationships between malnutrition, inflammation and atherosclerosis (MIA syndrome). Nephrol Dial Transplant. 2000;15(7):953-60

38. Topley N. In vitro biocompatibility of bicarbonate-based peritoneal dialysis solutions. Perit Dial Int. 1997:17(1):42-7.

39. Tarng DC, Wen Chen T, Huang TP, Chen CL, Liu TY, Wei YH. Increased oxidative damage to peripheral blood leukocyte DNA in chronic peritoneal dialysis patients. J Am Soc Nephrol. 2002;13(5):1321-30.

40. Ozden M, Maral H, Akaydin D, Cetinalp P, Kalender B. Erythrocyte glutathione peroxidase activity, plasma malondialdehyde and erythrocyte glutathione levels in hemodialysis and CAPD patients. Clin Biochem. 2002;35(4):269-73.

41. Vaziri ND. Oxidative stress in uremia: nature, mechanisms, and potential consequences. Semin Nephrol. 2004;24(5):469-73.

42. Hajnóczky G, Csordás G, Das S, Garcia-Perez C, Saotome M, Sinha Roy S, et al. Mitochondrial calcium signalling and cell death: approaches for assessing the role of mitochondrial Ca2+ uptake in apoptosis. Cell Calcium. 2006;40(5-6):553-60.

43. Ajioka RS, Phillips JD, Kushner JP. Biosynthesis of heme in mammals. Biochim Biophys Acta. 2006;1763(7):723-36.

44. Rossier MF. T channels and steroid biosynthesis: in search of a link with mitochondria. Cell Calcium. 2006;40(2):155-64.

45. Green DR. Apoptotic pathways: the roads to ruin. Cell. 1998;94(6):695-98

46. Cooper GM. The Cell: A Molecular Approach. 2nd edition. Sunderland (MA): Sinauer Associates; 2000. The Mechanism of Oxidative Phosphorylation. Available from: http://www.ncbi.nlm.nih.gov/books/NBK9885/ [accessed June 2, 2015].

47. Boveris A. Determination of the production of superoxide radicals and hydrogen peroxide in mitochondria. Methods Enzymol. 1984;105:429-35.

48. Che R, Yuan Y, Huang S, Zhang A. Mitochondrial dysfunction in the pathophysiology of renal diseases. Am J Physiol Renal Physiol. 2014;306(4):F367-78

49. Granata S, Zaza G, Simone S, Villani G, Latorre D, Pontrelli P, et al. Mitochondrial dysregulation and oxidative stress in patients with chronic kidney disease. BMC Genomics. 2009;10:388.

50. Su M, Dhoopun AR, Yuan Y, Huang S, Zhu C, Ding G, et al. Mitochondrial dysfunction is an early event in aldosterone-induced podocyte injury. Am J Physiol Renal Physiol. 2013;305(4):F520-31.

51. Yuan Y, Chen Y, Zhang P, Huang S, Zhu C, Ding G, et al. Mitochondrial dysfunction accounts for aldosterone-induced epithelial-to-mesenchymal transition of renal proximal tubular epithelial cells. Free Radic Biol Med 2012:53(1):30-43

52. Granata S, Masola V, Zoratti E, Scupoli MT, Baruzzi A, Messa M, et al. NLRP3 inflammasome activation in dialyzed chronic kidney disease patients. PLoS One. 2015;10(3), e0122272.

53. Zhuang Y, Yasinta M, Hu C, Zhao M, Ding G, Bai M, et al. Mitochondrial dysfunction confers albumin-induced NLRP3 inflammasome activation and renal tubular injury. Am J Physiol Renal Physiol. 2015;308(8):F857-66.

54. Zaza G, Granata S, Masola V, Rugiu C, Fantin F, Gesualdo L, et al. Downregulation of nuclear-encoded genes of oxidative metabolism in dialyzed chronic kidney disease patients. PLoS One. 2013;8, e77847.

55. Rebouche $\mathrm{CJ}$. Kinetics, pharmacokinetics, and regulation of L-carnitine and acetyl-L-carnitine metabolism. Ann N Y Acad Sci. 2004;1033:30-41.

56. Mayes PA. Lipids of physiologic significance. In: Murray RK, Granner DK Mayes PA, Rodwell WW, editors. Harper's Biochemistry. 25th ed. Stamford: Appleton and Lange; 2000. p. 160-71.

57. Gülçin I. Antioxidant and antiradical activities of L-carnitine. Life Sci. 2006;78(8):803-11

58. Kalaiselvi T, Panneerselvam C. Effect of L-carnitine on the status of liperoxidation and antioxidants in aging rats. J Nutr Biochem. 1998;9(10):575-81.

59. Rani PJ, Panneerselvam C. Effect of L-carnitine on brain lipid peroxidation and antioxidant enzymes in old rats. J Gerontol Biol Sci Med Sci. 2002;57(4):B134-7.

60. Sener G, Paskaloğlu K, Satiroglu H, Alican I, Kaçmaz A, Sakarcan A. Lcarnitine ameliorates oxidative damage due to chronic renal failure in rats. J Cardiovasc Pharmacol. 2004;43(5):698-705.

61. Bartel $L L$, Hussey $J L$, Shrago E. Perturbation of serum carnitine levels in human adults by chronic renal disease and dialysis therapy. Am J Clin Nutr. 1981;34(7):1314-20.

62. Guarnieri G, Toigo G, Crapesi L, Situlin R, Del Bianco MA, Corsi M, et al. Carnitine metabolism in chronic renal failure. Kidney Int. 1987;Suppl 22:S116-27.

63. Rodriguez-Segade S, Alonso de la Peña C, Paz JM, Novoa D, Arcocha V, Romero R, et al. Carnitine deficiency in haemodialysed patients. Clin Chim Acta. 1986;159:249-56.

64. Rodriguez-Segade S, Alonso de la Peña C, Paz M, Novoa D, Romero R, Arcocha V, et al. Carnitine concentrations in dialysed and undialysed patients with chronic renal insufficiency. Ann Clin Biochem. 1986;23:671-5.

65. Evans A. Dialysis-related carnitine disorder and levocarnitine pharmacology. Am J Kidney Dis. 2003:41 Suppl 4:S13-26.

66. Evans AM, Fornasini G. Pharmacokinetics of L-carnitine. Clin Pharmacokinet. 2003:42:941-67.

67. Ahmad S. L-carnitine in dialysis patients. Semin Dial. 2001;14:209-17.

68. Debska-Slizień KA, Wojnarowski K, Prajs J, Malgorzewicz S, Kunicka D, Zdrojewski Z, et al. Correlation between plasma carnitine, muscle carnitine and glycogen levels in maintenance hemodialysis patients. Int J Artif Organs. 2000;23:90-6.

69. Sakurauchi $Y$, Matsumoto $Y$, Shinzato T, Takai I, Nakamura $Y$, Sato M, et al. Effects of L-carnitine supplementation on muscular symptoms in hemodialyzed patients. Am J Kidney Dis. 1998;32:258-64.

70. Golper TA, Ahmad S. L-carnitine administration to hemodialysis patients: Has its time come? Semin Dial. 1992:5:94-8.

71. Karpati G, Carpenter S, Engel AG, Watters G, Allen J, Rothman S, et al. The syndrome of systemic carnitine deficiency. Clinical, morphologic, biochemical, and pathophysiologic features. Neurology. 1975;25(1):16-24.

72. Pertosa G, Grandaliano G, Simone S, Soccio M, Schena FP. Inflammation and carnitine in hemodialysis patients. J Ren Nutr. 2005;15(1):8-12.

73. Wasserstein AG. L-carnitine supplementation in dialysis: treatment in quest of disease. Semin Dial. 2013;26(1):11-5.

74. Duranay M, Akay H, Yilmaz FM, Senes M, Tekeli N, Yucel D. Effects of Lcarnitine infusions on inflammatory and nutritional markers in haemodialysis patients. Nephrol Dial Transplant. 2006;21(11):3211-4.

75. Savica V, Santoro D, Mazzaglia G, Ciolino F, Monardo P, Calvani M, et al. L-carnitine infusions may suppress serum C-reactive protein and improve nutritional status in maintenance hemodialysis patients. J Ren Nutr. 2005;15(2):225-30

76. Chen Y, Abbate M, Tang L, Cai G, Gong Z, Wei R, et al. L-Carnitine supplementation for adults with end-stage kidney disease requiring maintenance hemodialysis: a systematic review and meta-analysis. Am J Clin Nutr. 2014;99(2):408-22.

77. Fatouros IG, Douroudos I, Panagoutsos S, Pasadakis P, Nikolaidis MG, Chatzinikolaou $\mathrm{A}$, et al. Effects of L-carnitine on oxidative stress responses in patients with renal disease. Med Sci Sports Exerc. 2010;42(10):1809-18. 
78. Hurot JM, Cucherat M, Haugh M, Fouque D. Effects of L-carnitine supplementation in maintenance hemodialysis patients: a systematic review. J Am Soc Nephrol. 2002;13(3):708-14.

79. Food and Drug Administration, Center for Drug Evaluation and Research FDA approval letter for carnitor injection in dialysis. Available at http://www. accessdata.fda.gov/drugsatfda_docs/appletter/1999/20182S6LTR.PDF, accessed 29 October 2015.

80. Eknoyan $\mathrm{G}$, Latos $\mathrm{DL}$, Lindberg J. Practice recommendations for the use of L-carnitine in dialysis-related carnitine disorder. National kidney foundation carnitine consensus conference. Am J Kidney Dis. 2003:41:868-76.

81. Parikh S, Saneto R, Falk MJ, Anselm I, Cohen BH, Haas R, et al. A modern approach to the treatment of mitochondrial disease. Curr Treat Options Neurol. 2009;11(6):414-30.

82. Pravst I, Zmitek K, Zmitek J. Coenzyme Q10 contents in foods and fortification strategies. Crit Rev Food Sci Nutr. 2010;50(4):269-80.

83. Tomono Y, Hasegawa J, Seki T, Motegi K, Morishita N. Pharmacokinetic study of deuterium-labelled coenzyme Q10 in man. Int J Clin Pharmacol Ther Toxicol. 1986;24(10):536-41.

84. Ernster L, Dallner G. Biochemical, physiological and medical aspects of ubiquinone function. Biochim Biophys Acta. 1995;1271(1):195-204.

85. Papucci L, Schiavone N, Witort E, Donnini M, Lapucci A, Tempestini A, et al. Coenzyme Q10 prevents apoptosis by inhibiting mitochondrial depolarization independently of its free radical scavenging property. J Biol Chem. 2003;278(30):28220-8.

86. Echtay KS, Winkler $\mathrm{E}$, Frischmuth $\mathrm{K}$, Klingenberg M. Uncoupling proteins 2 and 3 are highly active $\mathrm{H}+$ transporters and highly nucleotide sensitive when activated by coenzyme Q (ubiquinone). Proc Natl Acad Sci U S A. 2001;98(4):1416-21.

87. Bergamini C, Moruzzi N, Sblendido A, Lenaz G, Fato R. A water soluble CoQ10 formulation improves intracellular distribution and promotes mitochondrial respiration in cultured cells. PLoS One. 2012;7, e33712.

88. Arroyo A, Navarro F, Gómez-Díaz C, Crane FL, Alcaín FJ, Navas P, et al. Interactions between ascorbyl free radical and coenzyme $Q$ at the plasma membrane. J Bioenerg Biomembr. 2000;32(2):199-210.

89. Constantinescu A, Maguire JJ, Packer L. Interactions between ubiquinones and vitamins in membranes and cells. Mol Aspects Med. 1994;15(Suppl):s57-65.

90. United States Renal Data System. 2014 USRDS annual data report: Epidemiology of kidney disease in the United States. Bethesda, MD: National Institutes of Health, National Institute of Diabetes and Digestive and Kidney Diseases; 2014.

91. Triolo L, Lippa S, Oradei A, De Sole P, Mori R. Mori Serum coenzyme Q10 in uremic patients on chronic hemodialysis. Nephron. 1994;66:153-6.

92. Burke BE, Neuenschwander R, Olson RD. Randomized, double-blind, placebo-controlled trial of coenzyme Q10 in isolated systolic hypertension. South Med J. 2001;94:1112-7.

93. Turkmen K, Ozbek O, Kayikcioğlu H, Kayrak M, Solak Y, Nayman A, et al. The relationship between epicardial adipose tissue and coronary artery calcification in peritoneal dialysis patients. Cardiorenal Med. 2012;2(1):43-51.

94. Atakan A, Macunluoglu B, Kaya Y, Ari E, Demir H, Asicioglu E, et al. Epicardial fat thickness is associated with impaired coronary flow reserve in hemodialysis patients. Hemodial Int. 2013;17:339-45.

95. lacobellis G, Corradi D, Sharma AM. Epicardial adipose tissue: anatomic biomolecular and clinical relationships with the heart. Nat Clin Pract Cardiovasc Med. 2005:2:536-43.

96. Corradi D, Maestri R, Callegari S, Pastori P, Goldoni M, Luong TV, et al. The ventricular epicardial fat is related to the myocardial mass in normal, ischemic and hypertrophic hearts. Cardiovasc Pathol. 2004;13:313-31610.

97. Sacks HS, Fain JN. Human epicardial adipose tissue: a review. Am Heart J. 2007:153:907-17.

98. Baker AR, Silva NF, Quinn DW, Harte AL, Pagano D, Bonser RS, et al. Human epicardial adipose tissue expresses a pathogenic profile of adipocytokines in patients with cardiovascular disease. Cardiovasc Diabetol. 2006;5:1.

99. Mazurek T, Zhang L, Zalewski A, Mannion JD, Diehl JT, Arafat H, et al. Human epicardial adipose tissue is a source of inflammatory mediators. Circulation. 2003;108(20):2460-6.

100. Sakata T, Furuya R, Shimazu T, Odamaki M, Ohkawa S, Kumagai H. Coenzyme Q10 administration suppresses both oxidative and antioxidative markers in hemodialysis patients. Blood Purif. 2008;26(4):371-8.

101. Macunluoglu B, Atakan A, Ari E, Kaya Y, Kaspar C, Demir H, et al. Epicardial fat tissue thickness is correlated with diminished levels of co-enzyme Q10, a major antioxidant molecule among hemodialysis patients. Clin Biochem. 2014:47(13-14):1231-4
102. Ishikawa A, Kawarazaki H, Ando K, Fujita M, Fujita T, Homma Y. Renal preservation effect of ubiquinol, the reduced form of coenzyme Q10. Clin Exp Nephrol. 2011;15(1):30-3.

103. Persson MF, Franzén S, Catrina SB, Dallner G, Hansell $P$, Brismar $K$, et al, Coenzyme Q10 prevents GDP-sensitive mitochondrial uncoupling, glomerular hyperfiltration and proteinuria in kidneys from $\mathrm{db} / \mathrm{db}$ mice as a model of type 2 diabetes. Diabetologia. 2012;55(5):1535-43.

104. Sourris KC, Harcourt BE, Tang PH, Morley AL, Huynh K, Penfold SA, et al. Ubiquinone (coenzyme Q10) prevents renal mitochondrial dysfunction in an experimental model of type 2 diabetes. Free Radic Biol Med. 2012;52(3):716-23.

105. Liu J. The effects and mechanisms of mitochondrial nutrient alpha-lipoic acid on improving age-associated mitochondrial and cognitive dysfunction: an overview. Neurochem Res. 2008:33(1):194-203.

106. Sigel H, Prijs B, McCormick DB, Shih JCH. Stability of binary and ternary complexes of a-lipoate and lipoate derivatives with $\mathrm{Mn} \mathrm{2+,} \mathrm{Cu} 2+$, and Zn 2+ in solution. Arch Biochem Biophys. 1978;187(1):208-14.

107. Packer L. alpha-Lipoic acid: a metabolic antioxidant which regulates NFkappa B signal transduction and protects against oxidative injury. Drug Metab Rev. 1998;30(2):245-75.

108. Petersen Shay K, Moreau RF, Smith EJ, Hagen TM. Is alpha-lipoic acid a scavenger of reactive oxygen species in vivo? Evidence for its initiation of stress signaling pathways that promote endogenous antioxidant capacity. IUBMB Life. 2008;60(6):362-7.

109. Kim H, Kim HJ, Lee K, Kim JM, Kim HS, Kim JR, et al. a-Lipoic acid attenuates vascular calcification via reversal of mitochondrial function and restoration of Gas6/Axl/Akt survival pathway. J Cell Mol Med. 2012;16(2):273-86.

110. Packer L, Witt EH, Tritschler HJ. Alpha-Lipoic acid as a biological antioxidant. Free Radic Biol Med. 1995;19(2):227-50.

111. Khabbazi T, Mahdavi R, Safa J, Pour-Abdollahi P. Effects of alpha-lipoic acid supplementation on inflammation, oxidative stress, and serum lipid profile levels in patients with end-stage renal disease on hemodialysis. J Ren Nutr 2012;22(2):244-50

112. Chang JW, Lee EK, Kim TH, Min WK, Chun S, Lee KU, et al. Effects of alphalipoic acid on the plasma levels of asymmetric dimethylarginine in diabetic end-stage renal disease patients on hemodialysis: a pilot study. Am J Nephrol. 2007:27(1):70-4

113. Ramos LF, Kane J, McMonagle E, Le P, Wu P, Shintani A, et al. Effects of combination tocopherols and alpha lipoic acid therapy on oxidative stress and inflammatory biomarkers in chronic kidney disease. J Ren Nutr. 2011;21(3):211-8.

114. Himmelfarb J, Ikizler TA, Ellis C, Wu P, Shintani A, Dalal S, et al. Provision of antioxidant therapy in hemodialysis (PATH): a randomized clinical trial. J Am Soc Nephrol. 2014;25(3):623-33.

115. Dinçer $Y$, Telci A, Kayali R, Yilmaz IA, Cakatay U, Akçay T. Effect of alphalipoic acid on lipid peroxidation and anti-oxidant enzyme activities in diabetic rats. Clin Exp Pharmacol Physiol. 2002;29:281-4.

116. Bast A, Haenen G. Lipoic acid: a multifunctional antioxidant. Biofactors 2003;17:207-13.

117. Maritim AC, Sanders RA, Watkins JB. Effects of alpha-lipoic acid on biomarkers of oxidative stress in streptozotocin-induced diabetic rats. J Nutr Biochem. 2003;14:288-94.

118. Obrosova IG, Fathallah L, Liu E, Nourooz-Zadeh J. Early oxidative stress in the diabetic kidney: Effect of DL-alpha-lipoic acid. Free Radic Biol Med. 2003;34:186-95.

119. Melhem MF, Craven PA, Liachenko J, De Rubertis FR. Alpha-lipoic acid attenuates hyperglycemia and prevents glomerular mesangial matrix expansion in diabetes. J Am Soc Nephrol. 2002;13:108-16.

120. Stillwell W, Ehringer W, Jenski LJ. Docosahexaenoic acid increases permeability of lipid vesicles and tumor cells. Lipids. 1993;28(2):103-8.

121. Stillwell W, Jenski LJ, Crump FT, Ehringer W. Effect of docosahexaenoic acid on mouse mitochondrial membrane properties. Lipids. 1997;32(5):497-506.

122. Calder PC. Omega-3 polyunsaturated fatty acids and inflammatory processes: nutrition or pharmacology? Br J Clin Pharmacol. 2013;75(3):645-62

123. Yaqoob P, Calder PC. Effects of dietary lipid manipulation upon inflammatory mediator production by murine macrophages. Cell Immunol. 1995;163(1):120-8.

124. Sadeghi S, Wallace FA, Calder PC. Dietary lipids modify the cytokine response to bacterial lipopolysaccharide in mice. Immunology. 1999:96(3):404-10.

125. Shing CM, Adams MJ, Fassett RG, Coombes JS. Nutritional compounds influence tissue factor expression and inflammation of chronic kidney disease patients in vitro. Nutrition. 2011;27(9):967-72. 
126. Novak TE, Babcock TA, Jho DH, Helton WS, Espat NJ. NF-kappa B inhibition by omega -3 fatty acids modulates LPS-stimulated macrophage TNF-alpha transcription. Am J Physiol Lung Cell Mol Physiol. 2003;284(1):L84-9.

127. Fischer $\mathrm{S}$, Weber PC. Prostaglandin $\mathrm{I} 3$ is formed in vivo in man after dietary eicosapentaenoic acid. Nature. 1984;307(5947):165-8.

128. Fischer $\mathrm{S}$, Weber $\mathrm{PC}$. Thromboxane $\mathrm{A} 3$ (TXA3) is formed in human platelets after dietary eicosapentaenoic acid (C20:5w-3). Biochem Biophys Res Commun. 1983;116(3):1091-9.

129. Needleman P, Raz A, Minkes MS, Ferrendelli JA, Sprecher $H$. Triene prostaglandins: prostacyclin and thromboxane biosynthesis and unique biological properties. Proc Natl Acad Sci U S A. 1979;76(2):944-8.

130. De Caterina R, Massaro M. Omega-3 fatty acids and the regulation of expression of endothelial pro-atherogenic and proinflammatory genes. J Membr Biol. 2005;206(2):103-16.

131. Gvozdjáková A, Pella D, Kucharská J, Otsuka K, Ram BS. Omega-3-PUFA, Omega-6-PUFA and Mitochondria. In: Mitochondrial medicine. 2008. p. 343-56.

132. Vaughan RA, Garcia-Smith R, Bisoffi M, Conn CA, Trujillo KA. Conjugated linoleic acid or omega 3 fatty acids increase mitochondrial biosynthesis and metabolism in skeletal muscle cells. Lipids Health Dis. 2012;11:142.

133. Arab K, Rossary A, Flourié F, Tourneur Y, Steghens JP. Docosahexaenoic acid enhances the antioxidant response of human fibroblasts by upregulating gamma-glutamyl-cysteinyl ligase and glutathione reductase. Br J Nutr. 2006;95(1):18-26.

134. Kim YJ, Chung HY. Antioxidative and anti-inflammatory actions of docosahexaenoic acid and eicosapentaenoic acid in renal epithelial cells and macrophages. J Med Food. 2007;10(2):225-31.

135. Hassan KS, Hassan SK, Hijazi EG, Khazim KO. Effects of omega-3 on lipid profile and inflammation markers in peritoneal dialysis patients. Ren Fail. 2010;32(9):1031-5.

136. Svensson M, Schmidt EB, Jørgensen KA, Christensen JH. The effect of n-3 fatty acids on lipids and lipoproteins in patients treated with chronic haemodialysis: a randomized placebo-controlled intervention study. Nephrol Dial Transplant. 2008;23(9):2918-24.

137. Harris WS. n-3 fatty acids and serum lipoproteins: Human studies. Am J Clin Nutr. 1997:65(5 Suppl):1645S-54S.

138. Deike E, Bowden RG, Moreillon JJ, Griggs JO, Wilson RL, Cooke M, et al. The effects of fish oil supplementation on markers of inflammation in chronic kidney disease patients. J Ren Nutr. 2012;22(6):572-7.

139. Hung AM, Booker C, Ellis CD, Siew ED, Graves AJ, Shintani A, et al. Omega-3 fatty acids inhibit the up-regulation of endothelial chemokines in maintenance hemodialysis patients. Nephrol Dial Transplant. 2015;30(2):266-74.

140. Poulia KA, Panagiotakos DB, Tourlede E, Rezou A, Stamatiadis D, Boletis J, et al. Omega-3 fatty acids supplementation does not affect serum lipids in chronic hemodialysis patients. J Ren Nutr. 2011;21(6):479-84.

141. Madsen T, Schmidt EB, Christensen $\mathrm{JH}$. The effect of $n-3$ fatty acids on Creactive protein levels in patients with chronic renal failure. J Ren Nutr. 2007;17(4):258-63.

142. Gharekhani A, Khatami MR, Dashti-Khavidaki S, Razeghi E, Noorbala AA, Hashemi-Nazari SS, et al. The effect of omega-3 fatty acids on depressive symptoms and inflammatory markers in maintenance hemodialysis patients: a randomized, placebo-controlled clinical trial. Eur J Clin Pharmacol. 2014;70(6):655-65.

143. Hoogeveen EK, Geleijnse JM, Kromhout D, Stijnen T, Gemen EF, Kusters R, et al. Effect of omega-3 fatty acids on kidney function after myocardial infarction: the Alpha Omega Trial. Clin J Am Soc Nephrol. 2014;9(10):1676-83.

144. Friedman AN, Yu Z, Tabbey R, Denski C, Tamez H, Wenger J, et al. Inverse relationship between long-chain $\mathrm{n}-3$ fatty acids and risk of sudden cardiac death in patients starting hemodialysis. Kidney Int. 2013;83(6):1130-5.

145. Hamazaki T, Nakazawa R, Tateno S, Shishido H, Isoda K, Hattori $Y$, et al. Effects of fish oil rich in eicosapentaenoic acid on serum lipid in hyperlipidemic hemodialysis patients. Kidney Int. 1984;26:81-4.

146. Rolf N, Tenschert W, Lison AE. Results of a long-term administration of omega-3 fatty acids in haemodialysis patients with dyslipoproteinaemia. Nephrol Dial Transplant. 1990;5:797-801.

147. Schmitz PG, McCloud LK, Reikes ST, Leonard CL, Gellens ME. Prophylaxis of hemodialysis graft thrombosis with fish oil: Double-blind, randomized, prospective trial. J Am Soc Nephrol. 2002;13:184-90.

148. Hombrouckx RO, Bogaert AM, Leroy FM, De Vos JY, Vermaercke NM, Picavet LM, et al. Polyunsaturated fatty acids of the $n-3$ class in chronic dialysis. ASAIO J. 1992;38:M331-3.
149. Donnelly SM, Ali MA, Churchill DN. Effect of $n-3$ fatty acids from fish oil on hemostasis, blood pressure, and lipid profile of dialysis patients. J Am Soc Nephrol. 1992;2:1634-9.

150. Khajehdehi P. Lipid-lowering effect of polyunsaturated fatty acids in hemodialysis patients. J Ren Nutr. 2000;10:191-5.

151. Bouzidi N, Mekki K, Boukaddoum A, Dida N, Kaddous A, Bouchenak M. Effects of omega-3 polyunsaturated fatty-acid supplementation on redox status in chronic renal failure patients with dyslipidemia. J Ren Nutr. 2010;20(5):321-8.

152. Maccarrone M, Taccone-Gallucci M, Finazzi-Agrò A. 5-Lipoxygenasemediated mitochondrial damage and apoptosis of mononuclear cells in ESRD patients. Kidney Int Suppl. 2003;84:S33-6.

153. Taccone-Gallucci M, Manca-di-Villahermosa S, Battistini L, Stuffler RG, Tedesco M, Maccarrone M. N-3 PUFAs reduce oxidative stress in ESRD patients on maintenance HD by inhibiting 5-lipoxygenase activity. Kidney Int. 2006:69(8):1450-4.

154. An WS, Kim HJ, Cho KH, Vaziri ND. Omega-3 fatty acid supplementation attenuates oxidative stress, inflammation, and tubulointerstitial fibrosis in the remnant kidney. Am J Physiol Renal Physiol. 2009;297(4):F895-903.

155. Teta D. Fish oil for prevention of sudden death in hemodialysis patients? Kidney Int. 2013;83(6):993-5.

156. IUPAC-IUB Joint Commission on Biochemical Nomenclature (JCBN). Nomenclature of tocopherols and related compounds. Recommendations 1981. Eur J Biochem. 1982:123(3):473-5.

157. Ando M, Yoshioka T, Akiyama J, Kudo T. Regulation of neutrophil superoxide generation by alpha-tocopherol in human peripheral and umbilical-cord blood. J Obstet Gynaecol Res. 1996;22:507-16.

158. Cachia O, Benna JE, Pedruzzi E, Descomp B, Gougert-Pocidalo M-A, Leger C-L. a-Tocopherol inhibits the respiratory burst in human monocytes. Attenuation of p47phox membrane translocation and phosphorylation. J Biol Chem. 1998:273:32801-5.

159. Chow CK, Ibrahim W, Wei Z, Chan AC. Vitamin E regulates mitochondrial hydrogen peroxide generation. Free Radic Biol Med. 1999;27(5-6):580-7.

160. Azzi A, Boscoboinik D, Fazzio A, Marilley D, Maroni P, Ozer NK, et al. RRRalpha-tocopherol regulation of gene transcription in response to cell oxidant status. Z Ernahrungswiss. 1998;37 Suppl 1:21-8.

161. Tasinato A, Boscoboinik D, Bartoli GM, Maroni P, Azzi A. D-Alpha-tocopherol inhibition of vascular smooth muscle cell proliferation occurs at physiological concentrations, correlates with protein kinase C inhibition, and is independent of its antioxidant properties. Proc Natl Acad Sci U S A. 1995;92:12190-94

162. Mahoney CW, Azzi A. Vitamin E inhibits protein kinase C activity. Biochem Biophys Res Commun. 1988;154(2):694-7.

163. Suzuki YJ, Packer L. Inhibition of NF-kappa B activation by vitamin E derivatives. Biochem Biophys Res Commun. 1993;193(1):277-83.

164. Kuemerle NB, Brandt RB, Chan W, Krieg Jr RJ, Chan JC. Inhibition of transforming growth factor beta-1 induction by dietary vitamin $\mathrm{E}$ in unilateral obstruction in rats Biochem. Mol Med. 1997:61:82-96.

165. Ekstrand-Hammarström B, Osterlund C, Lilliehöök B, Bucht A. Vitamin E down-modulates mitogen-activated protein kinases, nuclear factor-kappaB and inflammatory responses in lung epithelial cells. Clin Exp Immunol. 2007;147(2):359-69.

166. Gokce N, Frei B. Basic research in antioxidant inhibition of steps in atherogenesis. J Cardiovasc Risk. 1996:3(4):352-7.

167. Freedman JE, Farhat JH, Loscalzo J, Keaney Jr JF. Alpha-tocopherol inhibits aggregation of human platelets by a protein kinase C-dependent mechanism. Circulation. 1996;94(10):2434-40.

168. Azzi A, Aratri E, Boscoboinik D, Clément S, Ozer NK, Ricciarelli R, et al. Molecular basis of alpha-tocopherol control of smooth muscle cell proliferation. Biofactors. 1998;7(1-2):3-14.

169. Yu W, Heim K, Qian M, Simmons-Menchaca M, Sanders BG, Kline K. Evidence for role of transforming growth factor-beta in RRR-alphatocopheryl succinate-induced apotosis of human MDA-MB-435 breast cancer cells. Nutr Cancer. 1997;27(3):267-78.

170. Studer RK, Craven PA, DeRubertis FR. Antioxidant inhibition of protein kinase C-signaled increases in transforming growth factor-beta in mesangial cells. Metabolism. 1997:46(8):918-25.

171. Giray B, Kan E, Bali M, Hincal F, Basaran N. The effect of vitamin E supplementation on antioxidant enzyme activities and lipid peroxidation levels in hemodialysis patients. Clin Chim Acta. 2003;338(1-2):91-8.

172. Boudouris G, Verginadis II, Simos YV, Zouridakis A, Ragos V, Karkabounas SC, et al. Oxidative stress in patients treated with continuous ambulatory 
peritoneal dialysis (CAPD) and the significant role of vitamin C and $E$ supplementation. Int Urol Nephrol. 2013;45(4):1137-44.

173. Boaz M, Smetana S, Weinstein T, Matas Z, Gafter U, laina A, et al. Secondary prevention with antioxidants of cardiovascular disease in end stage renal disease (SPACE): randomised placebo-controlled trial. Lancet. 2000; 356(9237):1213-18.

174. Miller 3rd ER, Pastor-Barriuso R, Dalal D, Riemersma RA, Appel L, Guallar E. Meta-analysis: high-dosage vitamin E supplementation may increase allcause mortality. Ann Intern Med. 2005;142(1):37-46.

175. Kitamura Y, Kamimura K, Yoshioka N, Hosotani Y, Tsuchida K, Koremoto M, et al. The effect of vitamin E-bonded polysulfone membrane dialyzer on a new oxidative lipid marker. J Artif Organs. 2013;16(2):206-10.

176. Kirmizis D, Papagianni A, Belechri AM, Memmos D. Effects of vitamin E-coated membrane dialyser on markers of oxidative stress and inflammation in patients on chronic haemodialysis. Nephrol Dial Transplant. 2011;26(7):2296-301.

177. Takouli L, Hadjiyannakos D, Metaxaki P, Sideris V, Filiopoulos V, Anogiati A, et al. Vitamin E-coated cellulose acetate dialysis membrane: long-term effect on inflammation and oxidative stress. Ren Fail. 2010;32(3):287-93.

178. Panichi V, Rosati A, Paoletti S, Ferrandello P, Migliori M, Beati S, et al. A vitamin E-coated polysulfone membrane reduces serum levels of inflammatory markers and resistance to erythropoietin-stimulating agents in hemodialysis patients: results of a randomized cross-over multicenter trial. Blood Purif. 2011;32(1):7-14.

179. Yang CC, Hsu SP, Wu MS, Hsu SM, Chien CT. Effects of vitamin C infusion and vitamin E-coated membrane on hemodialysis-induced oxidative stress. Kidney Int. 2006;69(4):706-14.

180. Descamps-Latscha B, Drüeke T, Witko-Sarsat V. Dialysis-induced oxidative stress: biological aspects, clinical consequences, and therapy. Semin Dial. 2001;14(3):193-9.

181. Bakaev W, Efremov AV, Tityaev II. Low levels of dehydroascorbic acid in uraemic serum and the partial correction of dehydroascorbic acid deficiency by haemodialysis. Nephrol Dial Transplant. 1999;14(6):1472-4.

182. Nguyen-Khoa T, Massy ZA, De Bandt JP, Kebede M, Salama L, Lambrey G. Oxidative stress and haemodialysis: role of inflammation and duration of dialysis treatment. Nephrol Dial Transplant. 2001;16:335-40.

183. Deicher R, Horl WH. Vitamin C in chronic kidney disease and hemodialysis patients. Kidney Blood Press Res. 2003;26:100-6.

184. May JM, Qu ZC, Whitesell RR, Cobb CE. Ascorbate recycling in human erythrocytes: role of GSH in reducing dehydroascorbate. Free Radic Biol Med. 1996;20:543-51.

185. Zhang K, Li Y, Cheng X, Liu L, Bai W, Guo W, et al. Cross-over study of influence of oral vitamin C supplementation on inflammatory status in maintenance hemodialysis patients. BMC Nephrol. 2013;14:252.

186. Deved V, Poyah P, James MT, Tonelli M, Manns BJ, Walsh M, et al. Alberta Kidney Disease Network. Ascorbic acid for anemia management in hemodialysis patients: a systematic review and meta-analysis. Am J Kidney Dis. 2009;54(6):1089-97.

187. Bridges KR, Hoffman KE. The effects of ascorbic acid on the intracellular metabolism of iron and ferritin. J Biol Chem. 1986;261:14273-7.

188. Goldberg A. The enzymic formation of haem by the incorporation of iron into protoporphyrin; importance of ascorbic acid, ergothioneine and glutathione. Br J Haematol. 1959;5:150-7.

189. Dhar-Mascareño M, Cárcamo JM, Golde DW. Hypoxia-reoxygenationinduced mitochondrial damage and apoptosis in human endothelial cells are inhibited by vitamin C. Free Radic Biol Med. 2005;38:1311-22.

190. Perez-Cruz I, Carcamo JM, Golde DW. Vitamin C inhibits FAS-induced apoptosis in monocytes and U937 cells. Blood. 2003;102:336-43.

191. KC S, Cárcamo JM, Golde DW. Vitamin C enters mitochondria via facilitative glucose transporter 1 (Glut1) and confers mitochondrial protection against oxidative injury. FASEB J. 2005;19:1657-67.

192. Gruss-Fischer T, Fabian I. Protection by ascorbic acid from denaturation and release of cytochrome c, alteration of mitochondrial membrane potential and activation of multiple caspases induced by $\mathrm{H}_{2} \mathrm{O} 2$, in human leukemia cells. Biochem Pharmacol. 2002;63:1325-35.

193. Phillips JD. Medicinal plants. Biologist. 1992;39:187-91.

194. Ali BH, Blunden G. Pharmacological and toxicological properties of Nigella sativa. Phytother Res. 2003;17:299-305.

195. Al-Naqeeb G, Ismail M, Al-Zubairi AS. Fatty acid profile, a-tocopherol content and total antioxidant activity of Oil extracted from Nigella sativa seeds. Int J Pharmacol. 2009;5:244-50.
196. Ghosheh OA, Houdi AA, Crooks PA. High performance liquid chromatographic analysis of the pharmacologically active quinones and related compounds in the oil of the black seed (Nigella sativa L.). J Pharm Biomed Anal. 1999:19(5):757-62.

197. Badary OA, Taha RA, AM G e-D, Abdel-Wahab MH. Thymoquinone is a potent superoxide anion scavenger. Drug Chem Toxicol. 2003;26:87-98.

198. Burits M, Bucar F. Antioxidant activity of Nigella sativa essential oil. Phytother Res. 2000;14:323-8.

199. Meral I, Yener Z, Kahraman T, Mert N. Effect of Nigella sativa on glucose concentration, lipid peroxidation, anti-oxidant defence system and liver damage in experimentally-induced diabetic rabbits. J Vet Med A Physiol Pathol Clin Med. 2001;48:593-9.

200. Houghton PJ, Zarka R, De Las Heras B, Hoult JR. Fixed oil of Nigella sativa and derived thymoquinone inhibit eicosanoid generation in leukocytes and membrane lipid peroxidation. Planta Med. 1995;61:33-6.

201. Severina II, Severin FF, Korshunova GA, et al. In search of novel highly active mitochondria-targeted antioxidants: thymoquinone and its cationic derivatives. FEBS Lett. 2013;587:2018-24.

202. Basarslan F, Yilmaz N, Ates S, Ozgur T, Tutanc M, Motor VK. Protective effects of thymoquinone on vancomycin-induced nephrotoxicity in rats. Hum Exp Toxicol. 2012;31:726-33.

203. Badary OA, Nagi MN, al-Shabanah OA, al-Sawaf HA, al-Sohaibani MO, al-Bekairi AM. Thymoquinone ameliorates the nephrotoxicity induced by cisplatin in rodents and potentiates its antitumor activity. Can J Physiol Pharmacol. 1997;75:1356-61.

204. Ali BH. The effect of Nigella sativa oil on gentamicin nephrotoxicity in rats. Am J Chin Med. 2004;32:49-55.

205. Sayed-Ahmed MM, Nagi MN. Thymoquinone supplementation prevents the development of gentamicin-induced acute renal toxicity in rats. Clin Exp Pharmacol Physiol. 2007;34:399-405.

206. Badary OA, Abdel-Naim AB, Abdel-Wahab MH, Hamada FM. The influence of thymoquinone on doxorubicin-induced hyperlipidemic nephropathy in rats. Toxicology. 2000;143(3):219-26.

207. Zima T, Tesar V, Stípek S, Crkovská J, Poledne R, Tĕmínová J, et al. The influence of cyclosporin on lipid peroxidation and superoxide dismutase in adriamycin nephropathy in rats. Nephron. 1997;75(4):464-8.

208. Olson RD, Boerth RC, Gerber JG, Nies AS. Mechanism of adriamycin cardiotoxicity: evidence for oxidative stress. Life Sci. 1981;29(14):1393-401.

209. Khader M, Bresgen N, Eckl PM. In vitro toxicological properties of thymoquinone. Food Chem Toxicol. 2009;47(1):129-33.

210. Rooney S, Ryan MF. Effects of alpha-hederin and thymoquinone, constituents of Nigella sativa, on human cancer cell lines. Anticancer Res. 2005;25(3B):2199-204.

211. Gali-Muhtasib H, Diab-Assaf M, Boltze C, Al-Hmaira J, Hartig R, Roessner A, et al. Thymoquinone extracted from black seed triggers apoptotic cell death in human colorectal cancer cells via a p53-dependent mechanism. Int J Oncol. 2004:25(4):857-66.

212. Fujisawa S, Atsumi T, Ishihara M, Kadoma Y. Cytotoxicity, ROS-generation activity and radical-scavenging activity of curcumin and related compounds. Anticancer Res. 2004;24:563-9.

213. Calabrese V, Bates TE, Mancuso C, Cornelius C, Ventimiglia B, Cambria MT. Curcumin and the cellular stress response in free radical-related diseases. Mol Nutr Food Res. 2008;52:1062-73.

214. Aggarwal BB, Harikumar KB. Potential therapeutic effects of curcumin, the anti-inflammatory agent, against neurodegenerative, cardiovascular, pulmonary, metabolic, autoimmune and neoplastic diseases. Int J Biochem Cell Biol. 2009:41:40-59.

215. Ueki M, Ueno M, Morishita J, Maekawa N. Curcumin ameliorates cisplatininduced nephrotoxicity by inhibiting renal inflammation in mice. J Biosci Bioeng. 2013;115:547-51.

216. Mun SH, Joung DK, Kim YS, Kang OH, Kim SB, Seo YS. Synergistic antibacterial effect of curcumin against methicillin-resistant Staphylococcus aureus. Phytomedicine. 2013;20:714-8

217. Hatcher H, Planalp R, Cho J, Torti FM, Torti SV. Curcumin: from ancient medicine to current clinical trials. Cell Mol Life Sci. 2008;65(11):1631-52.

218. Aggarwal BB, Sung B. Pharmacological basis for the role of curcumin in chronic diseases: an Age-Old spice with modern targets. Trends Pharmacol Sci. 2009:30(2):85-94

219. Ghosh SS, Gehr TW, Ghosh S. Curcumin and chronic kidney disease (CKD): major mode of action through stimulating endogenous intestinal alkaline phosphatase. Molecules. 2014;19(12):20139-56.

220. Dinkova-Kostova AT, Talalay P. Direct and indirect antioxidant properties of inducers of cytoprotective proteins. Mol Nutr Food Res. 2008;52 Suppl 1:S128-38. 
221. Ak T, Gülçin I. Antioxidant and radical scavenging properties of curcumin. Chem Biol Interact. 2008;174(1):27-37.

222. Barzegar A, Moosavi-Movahedi AA. Intracellular ROS protection efficiency and free radical-scavenging activity of curcumin. PLoS One. 2011;6(10), e26012.

223. Das KC, Das CK. Curcumin (diferuloylmethane), a singlet oxygen ((1)O(2)) quencher. Biochem Biophys Res Commun. 2002;295(1):62-6.

224. Sreejayan RMN. Nitric oxide scavenging by curcuminoids. J Pharm Pharmacol. 1997;49(1):105-7.

225. Kim JE, Kim AR, Chung HY, Han SY, Kim BS, Choi JS. In vitro peroxynitrite scavenging activity of diarylheptanoids from Curcuma longa. Phytother Res. 2003;17(5):481-4

226. Subudhi U, Chainy GB. Curcumin and vitamin E modulate hepatic antioxidant gene expression in PTU-induced hypothyroid rats. Mol Biol Rep. 2012;39(11):9849-61.

227. Jeong GS, Oh GS, Pae HO, Jeong SO, Kim YC, Shin MK, et al. Comparative effects of curcuminoids on endothelial heme oxygenase-1 expression: ortho-methoxy groups are essential to enhance heme oxygenase activity and protection. Exp Mol Med. 2006;38(4):393-400.

228. Ye SF, Hou ZQ, Zhong LM, Zhang QQ. Effect of curcumin on the induction of glutathione S-transferases and $\operatorname{NADP}(H)$ :quinone oxidoreductase and its possible mechanism of action. Yao Xue Xue Bao. 2007;42(4):376-80.

229. Rushworth SA, Ogborne RM, Charalambos CA, O'Connell MA. Role of protein kinase $C$ delta in curcumin-induced antioxidant response elementmediated gene expression in human monocytes. Biochem Biophys Res Commun. 2006;341(4):1007-16.

230. Tapia E, Soto V, Ortiz-Vega KM, Zarco-Márquez G, Molina-Jijón E, Cristóbal-García M. Curcumin induces Nrf2 nuclear translocation and prevents glomerular hypertension, hyperfiltration, oxidant stress, and the decrease in antioxidant enzymes in 5/6 nephrectomized rats. Oxid Med Cell Longev. 2012;2012:269039.

231. Ghosh SS, Krieg R, Massey HD, Sica DA, Fakhry I, Ghosh S, et al. Curcumin and enalapril ameliorate renal failure by antagonizing inflammation in 5/6 nephrectomized rats: role of phospholipase and cyclooxygenase. Am J Physiol Renal Physiol. 2012;302(4):F439-54

232. Ghosh SS, Massey HD, Krieg R, Fazelbhoy ZA, Ghosh S, Sica DA. Curcumin ameliorates renal failure in 5/6 nephrectomized rats: role of inflammation. Am J Physiol Renal Physiol. 2009;296:F1146-57.

233. Sharma S, Kulkarni SK, Chopra K. Curcumin, the active principle of turmeric (Curcuma longa), ameliorates diabetic nephropathy in rats. Clin Exp Pharmacol Physiol. 2006:33:940-5.

234. Soetikno V, Watanabe K, Sari FR, Harima M, Thandavarayan RA, Veeraveedu PT, et al. Curcumin attenuates diabetic nephropathy by inhibiting PKC-a and PKC- $\beta 1$ activity in streptozotocin-induced type I diabetic rats. Mol Nutr Food Res. 2011;55:1655-65.

235. Antunes LM, Darin JD, Bianchi NL. Effects of the antioxidants curcumin or selenium on cisplatin-induced nephrotoxicity and lipid peroxidation in rats. Pharmacol Res. 2001:43:145-50.

236. Manikandan R, Beulaja M, Thiagarajan R, Priyadarsini A, Saravanan R, Arumugam M. Ameliorative effects of curcumin against renal injuries mediated by inducible nitric oxide synthase and nuclear factor kappa B during gentamicin-induced toxicity in Wistar rats. Eur J Pharmacol. 2011;670:578-85.

237. Venkatesan N, Punithavathi D, Arumugam V. Curcumin prevents adriamycin nephrotoxicity in rats. Br J Pharmacol. 2000;129:231-4.

238. Waly MI, Al Moundhri MS, Ali BH. Effect of curcumin on cisplatin- and oxaliplatin-induced oxidative stress in human embryonic kidney (HEK) 293 cells. Ren Fail. 2011;33:518-23.

239. Gupta SC, Patchva S, Aggarwal BB. Therapeutic roles of curcumin: lessons learned from clinical trials. AAPS J. 2013;15(1):195-218.

240. Khajehdehi P, Pakfetrat M, Javidnia K, Azad F, Malekmakan L, Nasab MH, et al. Oral supplementation of turmeric attenuates proteinuria, transforming growth factor-beta and interleukin-8 levels in patients with overt type 2 diabetic nephropathy: a randomized, double-blind and placebo-controlled study. Scand J Urol Nephrol. 2011;45(5):365-70.

241. Khajehdehi P, Zanjaninejad B, Aflaki E, Nazarinia M, Azad F, Malekmakan L, et al. Oral supplementation of turmeric decreases proteinuria, hematuria, and systolic blood pressure in patients suffering from relapsing or refractory lupus nephritis: a randomized and placebo-controlled study. J Ren Nutr. 2012;22(1):50-7.

242. Correa F, Buelna-Chontal M, Hernández-Reséndiz S, García-Niño WR, Roldán FJ, Soto V. Curcumin maintains cardiac and mitochondrial function in chronic kidney disease. Free Radic Biol Med. 2013;61:119-29.

243. Erlund I. Review of the flavonoids quercetin, hesperetin, and naringenin. Dietary sources, bioactivities, bioavailability, and epidemiology. Nutr Res. 2004;24:851-74.
244. Hanasaki Y, Ogawa S, Fukui S. The correlation between active oxygen scavenging and antioxidative effects of flavonoids. Free Radic Boil Med. 1994;6:845-53.

245. Plumb W, Price KR, Williamson G. Antioxidant properties of flavonol glycosides from green beans. Redox Rep. 1999;4:123-7.

246. Fiorani M, Sanctis R, Menghinello P, Cucchiarini L, Cellini B, Dacha M. Quercetin prevents glutathione depletion induced by dehydroascorbic acid in rabbit red blood cells. Free Radic Res. 2001;34:639-48.

247. Morand C, Crespy V, Manach C, Besson C, Demigne C, Remesy C. Plasma metabolites of quercetin and their antioxidant properties. Am J Physiol. 1998;75:R212-19.

248. Cho SY, Park SJ, Kwon MJ, Jeong TS, Bok SH, Choi WY, et al. Quercetin suppresses proinflammatory cytokines production through MAP kinases andNF-kappaB pathway in lipopolysaccharide-stimulated macrophage. Mol Cell Biochem. 2003;243(1-2):153-60.

249. Huang RY, Yu YL, Cheng WC, OuYang CN, Fu E, Chu CL. Immunosuppressive effect of quercetin on dendritic cell activation and function. J Immunol. 2010;184:6815-21.

250. Kim AR, Cho JY, Zou Y, Choi JS, Chung HY. Flavonoids differentially modulate nitric oxide production pathways in lipopolysaccharide-activated RAW264.7 cells. Arch Pharm Res. 2005;28:297-304.

251. Min YD, Choi CH, Bark H, Son HY, Park HH, Lee S. Quercetin inhibits expression of inflammatory cytokines through attenuation of NF-kB and p38 MAPK in HMC-1 human mast cell line. Inflamm Res. 2007;56:210-5.

252. Sanchez-Gonzalez PD, Lopez-Hernandez FJ, Perez-Barriocanal F, Morales Al, Lopez-Novoa JM. Quercetin reduces cisplatin nephrotoxicity in rats without compromising its anti-tumour activity. Nephrol Dial Transplant. 2011;26(11):3484-95.

253. Morales Al, Vicente-Sanchez C, Jerkic M, Santiago JM, Sánchez-González PD, Pérez-Barriocanal F.. Effect of quercetin on metallothionein, nitric oxide synthases and cyclooxygenase-2 expression on experimental chronic cadmium nephrotoxicity in rats. Toxicol Appl Pharmacol. 2006;210:128-35.

254. Erboga M, Aktas C, Erboga ZF, Donmez YB, Gurel A. Quercetin ameliorates methotrexate-induced renal damage, apoptosis and oxidative stress in rats. Ren Fail. 2015;37(9):1492-7.

255. Shoskes DA. Effect of bioflavonoids quercetin and curcumin on ischemic renal injury: a new class of renoprotective agents. Transplantation. 1998; 66(2):147-52.

256. Shoskes DA, Jones EA, Shahed A. Synergy of mycophenolate mofetil and bioflavonoids in prevention of immune and ischemic injury. Transplant Proc. 2000;32:798.

257. Jones EA, Shahed A, Shoskes DA. Modulation of apoptotic and inflammatory genes by bioflavonoids and angiotensin II inhibition in ureteral obstruction. Urology. 2000;56(2):346-51.

258. Mukhopadhyay A, Banerjee S, Stafford LJ, Xia C, Liu M, Aggarwal BB. Curcumin-induced suppression of cell proliferation correlates with downregulation of cyclin D1 expression and CDK4-mediated retnoblastoma protein phosphorylation. Oncogene. 2002;21(57):8852-61.

259. Gao X, Kuo J, Jiang H, Deeb D, Liu Y, Divine G. Immunomodulatory activity of curcumin: suppression of lymphocyte proliferation, development of cellmediated cytotoxicity, and cytokine production in vitro. Biochem Pharmacol. 2004;68:51.

260. Ranjan D, Chen C, Johnston TD, et al. Curcumin inhibits mitogen stimulated lymphocyte proliferation, NFkappaB activation, and IL-2 signaling. J Surg Res. 2004;121:171.

261. Shoskes DA, Thomas M, Pobgee R, Fromkin B, Copley JB. Phase I study of oral bioflavonoids in cadaveric renal transplant recipients: effects on delayed graft function and calcineurin inhibitor toxicities. Transplant Proc. 2003;35:841.

262. Shoskes D, Lapierre C, Cruz-Correa M, Muruve N, Rosario R, Fromkin B. Beneficial effects of the bioflavonoids curcumin and quercetin on early function in cadaveric renal transplantation: a randomized placebo controlled trial. Transplantation. 2005;80:1556-9.

263. Bach FH. Heme oxygenase-1 as a protective gene. Wien Klin Wochenschr. 2002;114 Suppl 4:1-3.

264. Coldiron Jr AD, Sanders RA, Watkins 3rd HB. Effects of combined quercetin and coenzyme Q10 treatment on oxidative stress in normal and diabetic rats. J Biochem Mol Toxicol. 2002;16:197-202.

265. Sanders RA, Rauscher FM, Watkins III JB. Effects of quercetin on antioxidant defence in streptozotocin-induced diabetic rats. J Biochem Mol Toxicol. 2001;15:143-9.

266. Anjaneyulu M, Chopra K. Quercetin, an anti-oxidant bioflavonoid, attenuates diabetic nephropathy in rats. Clin Exp Pharmacol Physiol. 2004;31:244-8. 
267. Davis JM, Murphy EA, Carmichael MD, Davis B. Quercetin increases brain and muscle mitochondrial biogenesis and exercise tolerance. Am J Physiol Regul Integr Comp Physiol. 2009;296:R1071-7.

268. Lagoa R, Graziani I, Lopez-Sanchez C, Garcia-Martinez V, Gutierrez-Merino C. Complex I and cytochrome $\mathrm{c}$ are molecular targets of flavonoids that inhibit hydrogen peroxide production by mitochondria. Biochim Biophys Acta. 1807;2011:1562-72.

269. Middleton Jr E. Effect of plant flavonoids on immune and inflammatory cell function. Adv Exp Med Biol. 1998;439:175-82.

270. Bertelli AA, Das DK. Grapes, wines, resveratrol, and heart health. J Cardiovasc Pharmacol. 2009:54:468-76.

271. Leonard SS, Xia C, Jiang BH, Stinefelt B, Klandorf H, Harris GK. Resveratrol scavenges reactive oxygen species and effects radical-induced cellular responses. Biochem Biophys Res Commun. 2003;309:1017-26.

272. Zhao L, Lee JY, Hwang DH. Inhibition of pattern recognition receptor-mediated inflammation by bioactive phytochemicals. Nutr Rev. 2011;69:310-20.

273. Sgambato A, Ardito R, Faraglia B, Boninsegna A, Wolf Fl, Cittadini A. Resveratrol, a natural phenolic compound, inhibits cell proliferation and prevents oxidative DNA damage. Mutat Res. 2001;496:171-80.

274. Aggarwal BB, Bhardwaj A, Aggarwal RS, Seeram NP, Shishodia S, Takada Y. Role of resveratrol in prevention and therapy of cancer: preclinical and clinical studies. Anticancer Res. 2004:24:2783-840.

275. Mokni M, Elkahoui S, Limam F, Amri M, Aouani E. Effect of resveratrol on antioxidant enzyme activities in the brain of healthy rat. Neurochem Res. 2007:32:981-7.

276. Um JH, Park SJ, Kang H, Yang S, Foretz M, McBurney MW, et al. AMP-activated protein kinase-deficient mice are resistant to the metabolic effects of resveratrol. Diabetes. 2010;59(3):554-63.

277. Yuan Y, Huang S, Wang W, Wang Y, Zhang P, Zhu C. Activation of peroxisome proliferator-activated receptor- $\gamma$ coactivator 1 a ameliorates mitochondrial dysfunction and protects podocytes from aldosterone-induced injury. Kidney Int. 2012;82:771-89.

278. Kimura Y, Okuda H, Arichi S. Effects of stilbenes on arachidonate metabolism in leukocytes. Biochim Biophys Acta. 1985;834(2):275-8.

279. Li J, Qu X, Ricardo SD, Bertram JF, Nikolic-Paterson DJ. Resveratrol inhibits renal fibrosis in the obstructed kidney: potential role in deacetylation of Smad3. Am J Pathol. 2010;177:1065-71.

280. Liang J, Tian S, Han J, Xiong P. Resveratrol as a therapeutic agent for renal fibrosis induced by unilateral ureteral obstruction. Ren Fail. 2014:36:285-91.

281. He W, Wang Y, Zhang MZ, You L, Davis LS, Fan H. Sirt1 activation protects the mouse renal medulla from oxidative injury. J Clin Invest. 2010;120:1056-68.

282. Huang XZ, Wen D, Zhang M, Xie Q, Ma L, Guan Y. Sirt1 activation ameliorates renal fibrosis by inhibiting the TGF- $\beta /$ Smad3 pathway. J Cell Biochem. 2014;115:996-1005.

283. He T, Guan X, Wang S, Xiao T, Yang K, Xu X. Resveratrol prevents high glucoseinduced epithelial-mesenchymal transition in renal tubular epithelial cells by inhibiting NADPH oxidase/ROS/ERK pathway. Mol Cell Endocrinol. 2015;402:13-20.

284. Zhang L, Pang S, Deng B, Qian L, Chen J, Zou J. High glucose induces renal mesangial cell proliferation and fibronectin expression through JNK/NF-KB/ NADPH oxidase/ROS pathway, which is inhibited by resveratrol. Int J Biochem Cell Biol. 2012;44:629-38.

285. Do Amaral CL, Francescato HD, Coimbra TM, Costa RS, Darin JD, Antunes LM. Resveratrol attenuates cisplatin-induced nephrotoxicity in rats. Arch Toxicol. 2008:82:363-70.

286. Bertelli AA, Migliori M, Panichi V, Origlia N, Filippi C, Das DK. Resveratrol, a component of wine and grapes, in the prevention of kidney disease. Ann NY Acad Sci. 2002;957:230-8.

287. Holthoff JH, Wang Z, Seely KA, Gokden N, Mayeux PR. Resveratrol improves renal microcirculation, protects the tubular epithelium, and prolongs survival in a mouse model of sepsis-induced acute kidney injury. Kidney Int. 2012;81:370-8.

288. Smoliga JM, Blanchard O. Enhancing the delivery of resveratrol in humans: if low bioavailability is the problem, what is the solution? Molecules. 2014;19:17154-72

289. Higdon JV, Frei B. Tea catechins and polyphenols: health effects, metabolism, and antioxidant functions. Crit Rev Food Sci Nutr. 2003;43:89-143.

290. Nanjo F, Mori M, Goto K, Hara Y. Radical scavenging activity of tea catechins and their related compounds. Biosci Biotechnol Biochem. 1999;63:1621-23.

291. Zhao B, Guo Q, Xin W. Free radical scavenging by green tea polyphenols. Methods Enzymolol. 2001;335:217-31.

292. Sutherland BA, Rahman RM, Appleton I. Mechanisms of action of green tea catechins, with a focus on ischemia-induced neurodegeneration. J Nutr Biochem. 2006;17(5):291-306.

293. Guo Q, Zhao B, Li M, Shen S, Xin W. Studies on protective mechanisms of four components of green tea polyphenols against lipid peroxidation in synaptosomes. Biochim Biophys Acta. 1996;1304(3):210-22.
294. Cabrera C, Artacho R, Giménez R. Beneficial effects of green tea-a review. J Am Coll Nutr. 2006:25:79-99.

295. Sarkar FH, Li Y, Wang Z, Kong D. Cellular signaling perturbation by natural products. Cell Signal. 2009;21(11):1541-7.

296. Ahn HY, Xu Y, Davidge ST. Epigallocatechin-3-O-gallate inhibits TNFalphainduced monocyte chemotactic protein-1 production from vascular endothelial cells. Life Sci. 2008;82(17-18):964-8.

297. Ahmed S, Marotte H, Kwan K, Ruth JH, Campbell PL, Rabquer BJ, et al. Epigallocatechin-3-gallate inhibits IL-6 synthesis and suppresses transsignaling by enhancing soluble gp130 production. Proc Natl Acad Sci U S A. 2008;105(38):14692-7.

298. Tedeschi E, Menegazzi M, Yao Y, Suzuki H, Förstermann U, Kleinert H. Green tea inhibits human inducible nitric-oxide synthase expression by downregulating signal transducer and activator of transcription-1a activation. Mol Pharmacol. 2004;65:111-20.

299. Qin S, Alcorn JF, Craigo JK, Tjoeng C, Tarwater PM, Kolls JK, et al. Epigallocatechin-3-gallate reduces airway inflammation in mice through binding to proinflammatory chemokines and inhibiting inflammatory cell recruitment. J Immunol. 2011;186(6):3693-700.

300. Ludwig A, Lorenz M, Grimbo N, Steinle F, Meiners S, Bartsch C, et al. The tea flavonoid epigallocatechin-3-gallate reduces cytokine-induced VCAM-1 expression and monocyte adhesion to endothelial cells. Biochem Biophys Res Commun. 2004;316(3):659-65.

301. Zhou P, Yu JF, Zhao CG, Sui FX, Teng X, Wu YB. Therapeutic potential of EGCG on acute renal damage in a rat model of obstructive nephropathy. Mol Med Rep. 2013;7:1096-102.

302. Wang Y, Wang B, Du F, Su X, Sun G, Zhou G, et al. Epigallocatechin-3-gallate attenuates oxidative stress and inflammation in obstructive nephropathy via $\mathrm{NF}-\mathrm{KB}$ and Nrf2/HO-1 signalling pathway regulation. Basic Clin Pharmacol Toxicol. 2015;117(3):164-72.

303. Wang Y, Wang B, Du F, Su X, Sun G, Zhou G. Epigallocatechin-3-gallate attenuates unilateral ureteral obstruction-induced renal interstitial fibrosis in mice. J Histochem Cytochem. 2014;30.

304. Yokozawa T, Rhyu DY, Cho EJ. (-)-Epicatechin 3-O-gallate ameliorates the damages related to peroxynitrite production by mechanisms distinct from those of other free radical inhibitors. J Pharm Pharmacol. 2004;56:231-9.

305. Yokozawa T, Oura H, Shibata T, Ishida K, Kaneko M, Hasegawa M. Effects of green tea tannin in dialysis patients. Journal of Traditional Medicines. 1996; 13(2):124-31.

306. Yokozawa T, Chung HY, He LQ, Oura H. Effectiveness of green tea tannin on rats with chronic renal failure. Biosci Biotechnol Biochem. 1996;60(6):1000-5.

307. Yamabe N, Yokozawa T, Oya T, Kim M. Therapeutic potential of (-)-epigallocatechin 3-O-gallate on renal damage in diabetic nephropathy model rats. J Pharmacol Exp Ther. 2006;319(1):228-36.

308. Rehman H, Krishnasamy Y, Haque K, Thurman RG, Lemasters JJ, Schnellmann RG. Green tea polyphenols stimulate mitochondrial biogenesis and improve renal function after chronic cyclosporin a treatment in rats. PLoS One. 2013;8:e65029.

309. El-Mowafy AM, Salem HA, Al-Gayyar MM, El-Mesery ME, El-Azab MF. Evaluation of renal protective effects of the green-tea (EGCG) and red grape resveratrol: role of oxidative stress and inflammatory cytokines. Nat Prod Res. 2011:25:850-6.

310. Salem EA, Salem NA, Kamel M, Maarouf AM, Bissada NK, Hellstrom WJ. Amelioration of gentamicin nephrotoxicity by green tea extract in uninephrectomized rats as a model of progressive renal failure. Ren Fail. 2010;32:1210-5.

311. Rushworth GF, Megson IL. Existing and potential therapeutic uses for Nacetylcysteine: the need for conversion to intracellular glutathione for antioxidant benefits. Pharmacol Ther. 2014;141:150-9.

312. Samuni Y, Goldstein S, Dean OM, Berk M. The chemistry and biological activities of N-acetylcysteine. Biochim Biophys Acta. 2013;1830(8):4117-29.

313. Sehirli AO, Sener G, Satiroglu H, Ayanoğlu-Dülger G. Protective effect of Nacetylcysteine on renal ischemia/reperfusion injury in the rat. J Nephrol. 2003;16(1):75-80

314. Ye J, Li J, Yu Y, Wei Q, Deng W, Yu L. L-carnitine attenuates oxidant injury in HK-2 cells via ROS-mitochondria pathway. Regul Pept. 2010;161(1-3):58-66.

315. Girouard H, Chulak C, Wu L, Lejossec M, de Champlain J. N-acetylcysteine improves nitric oxide and alpha-adrenergic pathways in mesenteric beds of spontaneously hypertensive rats. Am J Hypertens. 2003;16:577-84.

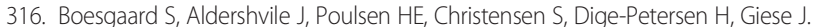
$\mathrm{N}$-acetylcysteine inhibits angiotensin converting enzyme in vivo. J Pharmacol Exp Ther. 1993;265:1239-44.

317. Baker CS, Wragg A, Kumar S, De Palma R, Baker LR, Knight CJ. A rapid protocol for the prevention of contrast-induced renal dysfunction: the RAPPID study. J Am Coll Cardiol. 2003;41:2114-8. 
318. Hsu TF, Huang MK, Yu SH, Yen DH, Kao WF, Chen YC. N-acetylcysteine for the prevention of contrast-induced nephropathy in the emergency department. Intern Med. 2012;51:2709-14.

319. Gurm HS, Smith DE, Berwanger O, Share D, Schreiber T, Moscucci M. BMC2 (Blue Cross Blue Shield of Michigan Cardiovascular Consortium). Contemporary use and effectiveness of $\mathrm{N}$-acetylcysteine in preventing contrast-induced nephropathy among patients undergoing percutaneous coronary intervention. JACC Cardiovasc Interv. 2012;5:98-104.

320. Aslanger E, Uslu B, Akdeniz C, Polat N, Cizgici Y, Oflaz H. Intrarenal application of $\mathrm{N}$-acetylcysteine for the prevention of contrast medium-induced nephropathy in primary angioplasty. Coron Artery Dis. 2012;23:265-70.

321. Heguilén RM, Liste AA, Payaslian M, Ortemberg MG, Albarracín LM, Bernasconi AR. N-acethyl-cysteine reduces the occurrence of contrastinduced acute kidney injury in patients with renal dysfunction: a singlecenter randomized controlled trial. Clin Exp Nephrol. 2013;17(3):396-404.

322. Shalansky SJ, Pate GE, Levin A, Webb JG. N-acetylcysteine for prevention of radiocontrast induced nephrotoxicity: the importance of dose and route of administration. Heart. 2005;91(8):997-9.

323. Fishbane S, Durham JH, Marzo K, Rudnick M. N-acetylcysteine in the prevention of radiocontrast-induced nephropathy. J Am Soc Nephrol. 2004;15(2):251-60.

324. Feldman L, Shani M, Efrati S, Beberashvili I, Yakov-Hai I, Abramov E. Nacetylcysteine improves residual renal function in peritoneal dialysis patients: a pilot study. Perit Dial Int. 2011;31:545-50.

325. Feldman L, Shani M, Sinuani I, Beberashvili I, Weissgarten J. N-acetylcysteine may improve residual renal function in hemodialysis patients: a pilot study. Hemodial Int. 2012;16:512-6.

326. Nascimento MM, Suliman ME, Silva M, Chinaglia T, Marchioro J, Hayashi SY. Effect of oral $\mathrm{N}$-acetylcysteine treatment on plasma inflammatory and oxidative stress markers in peritoneal dialysis patients: a placebocontrolled study. Perit Dial Int. 2010;30:336-42.

327. Tepel M, van der Giet M, Statz M, Jankowski J, Zidek W. The antioxidant acetylcysteine reduces cardiovascular events in patients with end-stage renal failure: a randomized, controlled trial. Circulation. 2003;107:992-5.

328. Trimarchi H, Mongitore MR, Baglioni P, Forrester M, Freixas EA, Schropp M, et al. $\mathrm{N}$-acetylcysteine reduces malondialdehyde levels in chronic hemodialysis patients—A pilot study. Clin Nephrol. 2003;59:441-6.

329. Renke M, Tylicki L, Rutkowski P, Larczynski W, Neuwelt A, Aleksandrowicz E. The effect of $\mathrm{N}$-acetylcysteine on blood pressure and markers of cardiovascular risk in non-diabetic patients with chronic kidney disease: a placebo-controlled, randomized, cross-over study. Med Sci Monit. 2010;16:113-8.

330. Moist L, Sontrop JM, Gallo K, Mainra R, Cutler M, Freeman D. Effect of Nacetylcysteine on serum creatinine and kidney function: results of a randomized controlled trial. Am J Kidney Dis. 2010;56:643-50.

331. Renke M, Tylicki L, Rutkowski P, Larczyński W, Aleksandrowizz E, Lysiak-Szydłowska $W$. The effect of $\mathrm{N}$-acetylcysteine on proteinuria and markers of tubular injury in non-diabetic patients with chronic kidney disease. A placebo-controlled, randomized, open, cross-over study. Kidney Blood Press Res. 2008;31:404-10.

332. Burgunder JM, Varriale A, Lauterburg BH. Effect of $\mathrm{N}$-acetylcysteine on plasma cysteine and glutathione following paracetamol administration. Eur J Clin Pharmacol. 1989;36:127-31.

333. Kleinveld HA, Demacker PN, Stalenhoef AF. Failure of N-acetylcysteine to reduce low-density lipoprotein oxidizability in healthy subjects. Eur J Clin Pharmacol. 1992;43:639-42.

334. Bielecka-Dabrowa, Aronow WS, Rysz J, Banach M. Current place of betablockers in the treatment of hypertension. Curr Vasc Pharmacol. 2010;8:733-41.

335. Dulin B, Abraham WT. Pharmacology of carvedilo. Am J Cardiol. 2004;93:3B-6B.

336. Noguchi N, Nishino K, Niki E. Antioxidant action of the antihypertensive drug, carvedilol, against lipid peroxidation. Biochem Pharmacol. 2000;59:1069-76.

337. Rodrigues MA, Rodrigues JL, Martins NM, Barbosa F, Curti C, Santos NA. Carvedilol protects against cisplatin-induced oxidative stress, redox state unbalance and apoptosis in rat kidney mitochondria. Chem Biol Interact. 2011;189:45-51.

338. Rodrigues MA, Rodrigues IL, Martins NM, Barbosa F, Curti C, Santos NA. Carvedilol protects against the renal mitochondrial toxicity induced by cisplatin in rats. Mitochondrion. 2010;10:46-53.

339. Padi SS, Chopra K. Salvage of cyclosporine A-induced oxidative stress and renal dysfunction by carvedilol. Nephron. 2002;92:685-92.

340. Singh D, Chander V, Chopra K. Carvedilol attenuates ischemia-reperfusioninduced oxidative renal injury in rats. Fundam Clin Pharmacol. 2004;18:627-34.

341. Kumar KV, Shifow AA, Naidu MU, Ratnakar KS. Carvedilol: a beta blocker with antioxidant property protects against gentamicin-induced nephrotoxicity in rats. Life Sci. 2000;66:2603-11.
342. Ghazi-Khansari M, Nasiri G, Honarjoo M. Decreasing the oxidant stress from paraquat in isolated perfused rat lung using captopril and niacin. Arch Toxicol. 2005;79:341-5.

343. de Cavanagh EM, Fraga CG, Ferder L, Inserra F. Enalapril and captopril enhance antioxidant defenses in mouse tissues. Am J Physiol. 1997;272:R514-8.

344. Efrati S, Berman S, Hamad RA, Siman-Tov Y, Ilgiyaev E, Maslyakov I. Effect of captopril treatment on recuperation from ischemia/reperfusion-induced acute renal injury. Nephrol Dial Transplant. 2012;27:136-45.

345. Sanchez-Lozada LG, Soto V, Tapia E, Avila-Casado C, Sautin YY, Nakagawa T. Role of oxidative stress in the renal abnormalities induced by experimental hyperuricemia. Am J Physiol. 2008;295:F1134-41.

346. Sanchez-Lozada LG, Tapia E, Lopez-Molina R, Nepomuceno T, Soto V, Avila-Casado C. Effects of acute and chronic L-arginine treatment in experimental hyperuricemia. Am J Physiol. 2007;292:F1238-44.

347. Sanchez-Lozada LG, Tapia E, Santamaria J, Avila-Casado C, Soto V, Nepomuceno T. Mild hyperuricemia induces vasoconstriction and maintains glomerular hypertension in normal and remnant kidney rats. Kidney Int. 2005;67:237-47.

348. Ryu E-S, Kim MJ, Shin H-S, Jang YH, Choi HS, Jo L.. Uric acid-induced phenotypic transition of renal tubular cells as a novel mechanism of chronic kidney disease. Am J Physiol. 2013;304:F471-80.

349. Rao GN, Corson MA, Berk BC. Uric acid stimulates vascular smooth muscle cell proliferation by increasing platelet derived growth factor A-chain expression. J Biol Chem. 1991;266:8604-8.

350. Corry DB, Eslami P, Yamamoto K, Nyby MD, Makino H, Tuck ML. Uric acid stimulates vascular smooth muscle cell proliferation and oxidative stress via the vascular renin-angiotensin system. J Hypertens. 2008;26:269-75.

351. Kanellis J, Watanabe S, Li JH, Kang DH, Li P, Nakagawa T, et al. Uric acid stimulates MCP-1 production in vascular smooth muscle cells via MAPK and COX-2. Hypertension. 2003:41:1287-93.

352. Yu MA, Sánchez-Lozada LG, Johnson RJ, Kang DH. Oxidative stress with an activation of the renin-angiotensin system in human vascular endothelial cells as a novel mechanism of uric acid-induced endothelial dysfunction. J Hypertens. 2010;28(6):1234-42.

353. Perlstein TS, Gumieniak O, Hopkins PN, Murphey LJ, Brown NJ, Williams GH, et al. Uric acid and the state of the intrarenal renin-angiotensin system in humans. Kidney Int. 2004;66(4):1465-70.

354. Sanchez-Lozada LG, Lanaspa MA, Cristobal-Garcia M, García-Arroyo F, Soto V, Cruz-Robles D. Uric acid-induced endothelial dysfunction is associated with mitochondrial alterations and decreased intracellular ATP concentrations. Nephron Exp Nephrol. 2012;121:e71-8.

355. Cristóbal-García M, García-Arroyo FE, Tapia E, Osorio H, Arellano-Buendía AS, Madero M, et al. Renal oxidative stress induced by long-term hyperuricemia alters mitochondrial function and maintains systemic hypertension. Oxid Med Cell Longev. 2015;2015:535686.

356. Siu YP, Leung KT, Tong MK, Kwan TH. Use of allopurinol in slowing the progression of renal disease through its ability to lower serum uric acid level. Am J Kidney Dis. 2006;47(1):51-9.

357. Goicoechea M, Garcia de Vinuesa S, Verdalles U, Verde E, Macias N, Santos A. Allopurinol and Progression of CKD and Cardiovascular Events: Long-term Follow-up of a Randomized Clinical Trial. Am J Kidney Dis. 2015;65(4):543-9.

358. Bayram D, Tuğrul Sezer M, Inal S, Altuntaş A, Kıdır V, Orhan H. The effects of allopurinol on metabolic acidosis and endothelial functions in chronic kidney disease patients. Clin Exp Nephrol. 2015;19(3):443-9.

359. Ng KP, Stringer SJ, Jesky MD, Yadav P, Athwal R, Dutton M. Allopurinol is an independent determinant of improved arterial stiffness in chronic kidney disease: a cross-sectional study. PLoS One. 2014;9:e91961.

360. Kao MP, Ang DS, Gandy SJ, Nadir MA, Houston JG, Lang CC. Allopurinol benefits left ventricular mass and endothelial dysfunction in chronic kidney disease. J Am Soc Nephrol. 2011;22:1382-9.

361. Goicoechea M, de Vinuesa SG, Verdalles U, Ruiz-Caro C, Ampuero J, Rincón A. Effect of allopurinol in chronic kidney disease progression and cardiovascular risk. Clin J Am Soc Nephrol. 2010;5:1388-93.

362. Murphy MP, Smith RAJ. Drug delivery to mitochondria: the key to mitochondrial medicine. Adv Drug Deliv Rev. 2000:41:235-50.

363. Ross MF, Kelso GF, Blaikie FH, James AM, Cochemé HM, Filipovska A, et al. Lipophilic triphenylphosphonium cations as tools in mitochondrial bioenergetics and free radical biology. Biochemistry (Mosc). 2005;70(2):222-30.

364. Smith RAJ, Porteous CM, Coulter CV, Murphy MP. Targeting an antioxidant to mitochondria. Eur J Biochem. 1999;263:709-16.

365. Murphy MP, Smith RA. Targeting antioxidants to mitochondria by conjugation to lipophilic cations. Annu Rev Pharmacol Toxicol. 2007;47:629-56. 
366. Kelso GF, Porteous CM, Coulter CV, Hughes G, Porteous WK, Ledgerwood $\mathrm{EC}$, et al. Selective targeting of a redox-active ubiquinone to mitochondria within cells: antioxidant and antiapoptotic properties. J Biol Chem. 2001;276(7):4588-96375.

367. Smith RAJ, Porteous CM, Gane AM, Murphy MP. Delivery of bioactive molecules to mitochondria in vivo. Proc Natl Acad Sci U S A. 2003:100:5407-12.

368. Adlam VJ, Harrison JC, Porteous CM, James AM, Smith RA, Murphy MP, et al. Targeting an antioxidant to mitochondria decreases cardiac ischemiareperfusion injury. FASEB J. 2005;19(9):1088-95.

369. Graham D, Huynh NN, Hamilton CA, Beattie E, Smith RA, Cochemé HM. The mitochondria targeted antioxidantMitoQ10 improves endothelial function and attenuates cardiac hypertrophy. Hypertension. 2009;54:322-8.

370. Mitchell T, Rotaru D, Saba H, Smith RA, Murphy MP, MacMillan-Crow LA. The mitochondria-targeted antioxidant mitoquinone protects against cold storage injury of renal tubular cells and rat kidneys. J Pharmacol Exp Ther. 2011;336(3):682-92.

371. Parajuli N, Campbell LH, Marine A, Brockbank KG, Macmillan-Crow LA. MitoQ blunts mitochondrial and renal damage during cold preservation of porcine kidneys. PLoS One. 2012;7, e48590.

372. Dare AJ, Bolton EA, Pettigrew GJ, Bradley JA, Saeb-Parsy K, Murphy MP. Protection against renal ischemia-reperfusion injury in vivo by the mitochondria targeted antioxidant MitoQ. Redox Biol. 2015;5:163-8.

373. Chacko BK, Reily C, Srivastava A, Johnson MS, Ye Y, Ulasova E, et al. Prevention of diabetic nephropathy in $\ln 22(+/)^{-}$(AkitaJ) mice by the mitochondria-targeted therapy MitoQ. Biochem J. 2010;432(1):9-19.

374. Gane EJ, Weilert F, Orr DW, Keogh GF, Gibson M, Lockhart MM, et al. The mitochondria-targeted anti-oxidant mitoquinone decreases liver damage in a phase II study of hepatitis C patients. Liver Int. 2010;30(7):1019-26.

375. Snow BJ, Rolfe FL, Lockhart MM, Frampton CM, O'Sullivan JD, Fung V, et al. A double-blind, placebo-controlled study to assess the mitochondriatargeted antioxidant MitoQ as a disease-modifying therapy in Parkinson's disease. Mov Disord. 2010;25(11):1670-4.

376. Kelso GF, Maroz A, Cochemé HM, Logan A, Prime TA, Peskin AV, et al. A mitochondria-targeted macrocyclic Mn(II) superoxide dismutase mimetic. Chem Biol. 2012;19(10):1237-46.

377. Salvemini D, Wang ZQ, Zweier JL, Samouilov A, Macarthur $H$, et al. A nonpeptidyl mimic of superoxide dismutase with therapeutic activity in rats. Science. 1999:286:304-6.

378. Dikalova AE, Bikineyeva AT, Budzyn K, Nazarewicz RR, McCann L, et al. Therapeutic targeting of mitochondrial superoxide in hypertension. Circ Res. 2010;107:106-16.

379. Patil NK, Parajuli N, MacMillan-Crow LA, Mayeux PR. Inactivation of renal mitochondrial respiratory complexes and manganese superoxide dismutase during sepsis: mitochondria-targeted antioxidant mitigates injury. Am J Physiol Renal Physiol. 2014;306(7):F734-43.

380. Zhao K, Luo G, Zhao GM, Schiller PW, Szeto HH. Transcellular transport of a highly polar 3+ net charge opioid tetrapeptide. J Pharmacol Exp Ther. 2003;304(1):425-32.

381. Zhao K, Zhao GM, Wu D, Soong Y, Birk AV, Schiller PW. Cell-permeable peptide antioxidants targeted to inner mitochondrial membrane inhibit mitochondrial swelling, oxidative cell death, and reperfusion injury. J Biol Chem. 2004;279(33):34682-90.

382. Szeto HH. Cell-permeable, mitochondrial-targeted, peptide antioxidants. AAPS J. 2006;8(2):E277-83.

383. Zhao K, Luo G, Giannelli S, Szeto HH. Mitochondria targeted peptide prevents mitochondrial depolarization and apoptosis induced by tert-butyl hydroperoxide in neuronal cell lines. Biochem Pharmacol. 2005;70:1796-806.

384. Cho J, Won K, Soong Y, Liu S, Szeto HH, Hong MK. Potent mitochondriatargeted peptides reduce myocardial infarction in rats. Coronary Artery Dis. 2007:18:215-20.

385. Cho S, Szeto HH, Kim Pinto JTHJ. A novel cell permeable antioxidant peptide, SS31, attenuates ischemic brain injury by down-regulating CD36. J Biol Chem. 2007;282:4634-42.

386. Petrie S, Kiaei M, Damiano M, Hiller A, Wille E, Manfredi G, et al. Cell-permeable peptide antioxidants as a novel therapeutic approach in a mouse model of amyotrophic lateral sclerosis. J Neurochem. 2006:98:1141-9.

387. Thomas DA, Stauffer C, Zhao K, Yang H, Sharma VK, Szeto HH, et al. Mitochondrial targeting with antioxidant peptide SS-31 prevents mitochondrial depolarization, reduces islet cell apoptosis, increases islet cell yield, and improves posttransplantation function. J Am Soc Nephrol. 2007;18(1):213-22
388. Wu D, Soong Y, Zhao G, Szeto HH. A highly potent peptide analgesic that protects against ischemia-reperfusion-induced myocardial stunning. Am J Physiol Heart Circ Physiol. 2002;283:H783-91.

389. Mizuguchi Y, Chen J, Seshan SV, Poppas DP, Szeto HH, Felsen D. A nove cell-permeable antioxidant peptide decreases renal tubular apoptosis and damage in unilateral ureteral obstruction. Am J Physiol Renal Physiol. 2008;295(5):F1545-53.

390. Szeto HH, Liu S, Soong Y, Wu D, Darrah SF, Cheng FY. Mitochondria-targeted peptide accelerates ATP recovery and reduces ischemic kidney injury. J Am Soc Nephrol. 2011;22:1041-52.

391. Liu S, Soong Y, Seshan SV, Szeto HH. Novel cardiolipin therapeutic protects endothelial mitochondria during renal ischemia and mitigates microvascular rarefaction, inflammation, and fibrosis. Am J Physiol Renal Physiol. 2014;306(9):F970-80

392. Birk AV, Liu S, Soong Y, Mills W, Singh P, Warren JD, et al. The mitochondrial-targeted compound SS-31 re-energizes mitochondria by interacting with cardiolipin. J Am Soc Nephrol. 2013;24:1250-61.

393. Cerrato CP, Pirisinu M, Vlachos EN, Langel Ü. Novel cell-penetrating peptide targeting mitochondria. FASEB J. 2015;29(11):4589-99.

394. Fawell S, Seery J, Daikh Y, Moore C, Chen LL, Pepinsky B, et al. Tat-mediated delivery of heterologous proteins into cells. Proc Natl Acad Sci U S A. 1994;91(2):664-8.

395. Zaza G, Granata S, Sallustio F, Grandaliano G, Schena FP. Pharmacogenomics: a new paradigm to personalize treatments in nephrology patients. Clin Exp Immunol. 2010;159(3):268-80.

\section{Submit your next manuscript to BioMed Central and we will help you at every step:}

- We accept pre-submission inquiries

- Our selector tool helps you to find the most relevant journal

- We provide round the clock customer support

- Convenient online submission

- Thorough peer review

- Inclusion in PubMed and all major indexing services

- Maximum visibility for your research 